\title{
Türk Sağlık Sisteminde Dış Kaynaklardan Yararlanma Uygulamalarının Yasal Altyapısı
}

\author{
Çağdaş Erkan AKYÜREK \\ Hacettepe Üniversitesi İ.İ.B.F. Sağlık İdaresi Bölümü, Ankara, Türkiye \\ cagdaserkan.akyurek@hacettepe.edu.tr
}

\begin{abstract}
Özet
Artan maliyetler günümüzde tüm sağllk hizmeti sistemlerinin en temel sorunu haline gelmiştir. Öyle ki verimlilik, etkililik ve kalite gibi öncelikli hedeflerin önünde duran maliyet sorunu hemen hemen her modern yönetim tekniğinin üstesinden gelmeye çalıştı̆̆ bir sorun durumundadır. Bu modern yönetim tekniklerinden biri olan Dış Kaynaklardan Yararlanma, Türk Kamu Sektörü'nde de kendisine geniş uygulama bulmuş ve önemli finansal büyüklüklere ulaşmışıır. Bu denli yaygın ve önemli miktarda fonla ilintili uygulamalara ait yasal altyapının yöneticilerce iyi bilinmesi kaçınılmaz bir gerekliliktir. Bu çalışmada öncelikle kavramsal olarak Dış Kaynaklardan Yararlanma irdelenmiş, ardından Türk Kamu Sektörü'nde Dış Kaynaklardan Yararlanma uygulamalarının hukuki altyapısına ve bu yapı içerisinde gerçekleştirilen kamu alım süreçlerine değinilmiştir. Son beş yıllık zaman dilimine ait kamu alım istatistikleriyle çalışma desteklenmiştir.
\end{abstract}

Anahtar Kelimeler: Dış Kaynaklardan Yararlanma, Sağlık Hizmetleri, Kamu İhale Kanunu, Kamu İhaleleri Sözleşme Kanunu

\begin{abstract}
Rising costs, nowadays, has became the basic problem of all healthcare systems. Infact, rising costs which stands on the way of ultimate goals such as efficiency, effectiveness and quality is a problem that almost modern management techniques have been trying to overcome. Outsourcing, one of these modern management techniques, has found itself a large application area and has reached to an important financial size in Turkish Public Sector. It is an unavoidable necessity for managers to understand the legal infrastructure of these interventions which are prevalent and connecting huge funds. In this study, first of all outsourcing is scrutinized in conceptual context, and then the legal infrastructure of outsourcing activities in Turkish Public Sector and the public sourcing processes carried out in this infrastructure were mentioned. The study is supported with the public sourcing statistics belongs to last five year time period.
\end{abstract}

Keywords: Outsourcing, Heatlhcare Services, Public Procurement Law, Public Procurement Contracts Law. 


\section{Giriş}

Ekonomilerin sadece parasal boyutuyla algılanır olduğu, rekabetin ölümcül boyutlara ulaştığı, etkililik ve verimlilik gibi kavramların tek başlarına çözüm olarak kabul edildiği bir çevrede örgütlerin başvurduğu ya da çoğu zaman kaçınılmaz biçimde karşı karşıya kaldığı bir fenomen olan Dış Kaynaklardan Yararlanma (DKY), Türk Sağlık Sistemi'nde 1990'lı yıllardan bu yana sürekli gelişmiş, üretim ve işlemler yönetimi sürecinde önemli finansal büyüklüğe erişmiştir. Özelleştirme tartışmaları henüz sürerken kimilerinin "ver, kurtul”, kimilerinin "örgütün içi boşalıyor" türünden tepkiler verdiği, kimilerininse kaçınılmaz kabul ettiği DKY esasen bir örgütün kendi kaynaklarıyla yürüttüğü bazı hizmet veya fonksiyonların, bir sözleşme çerçevesinde, asli sorumluluğu yine örgütte kalmak üzere bir dış tedarikçiye devredilmesidir.

DKY kavramı ile eş zamanlı biçimde üzerinde durulması gereken başka bir kavram ise özelleştirmedir. Kavramsal açıdan sınırları halen tam anlamıyla çizilmemiş olsa da özelleştirme, kamu örgütlerinde verimliliğin ve etkililiğin önündeki engelleri özel sektörün içerdiği teşviklere konu etme yönündeki genel çabadır. Özelleştirme kavramı farklı pek çok şekilde özel sektör ile kamu sektörü arasındaki ilişkilerin değiștirilmesini içermektedir. Çok daha yalın bir ifadeyle özelleştirme kamu mülkiyetinde bulunan varlıkların, bireylere ya da özel sektör üyesi örgütlere satışıdır. Fakat bu tanımın özelleştirmeyi gerçek içeriğine kıyasla oldukça sınırlandırdığını belirtmek doğru olacaktır. Çünkü özelleştirme daha geniş bir bakış açısıyla devletin rolünün sınırlandırılmasını ve buna paralel olarak serbest piyasa ekonomisini güçlendirecek yöntem ve politikaların hayata geçirilmesini de kapsamaktadır (Aktan, 2004).

Sağlık reformlarının küresel bileşeni olan özelleştirme, 1980'li yılların muhafazakâr hükümetlerinin monetarist ekonomik politikaları sonucunda gündemdeki yerini almıştır. Sağlık hizmetlerinin özelleştirilmesi bir örgütlenme modelinden çok, sağlık sektörünün finans sorununa çözüm üretecek bir model olarak ele alınmakta ve sunulmaktadır.

Farklı ülkelerde değişik nesnel dinamikler üzerinde gelişen ve savunulmasında da değişik argümanlara başvurulan özelleştirmeye sağlık alanında ivme kazandıran hususlar kamu sağlık kurumlarının yıpranmışlığı ve boğuştuğu sorunların çözümsüz bir döngüye girmiş olmasıdır. Özelleştirmeye yönelik en temel eleştiri ise, özelleştirmenin verimlilik, etkililik ve eşitlik gibi kimi teknik sorunlara çözüm üretecek kültürel bir öneri olarak değil, bir bütün olarak kapitalist sınıfı içine düştüğü bunalımdan kurtarma amacı taşıyan ciddi bir ekonomik ve politik operasyon olduğu yönündedir (Belek, 1994).

Son 50-60 yıllık zaman zarfinda farklı isim ve yüzlerle karşımıza çıkmış olsa da popülerliğini daima korumayı başarmış ve özellikle hizmet sunumu maliyetlerinin örgütleri bunaltacak seviyede seyrettiği dönemlerde özelleştirme uygulamasının bir uzantısı olarak hep ilk sıralarda akla gelmiş stratejik bir seçenek konumundaki DKY en sık dile getirilen tanımıyla, daha önce de ifade edildiği üzere, bir örgütün daha önce kendi işgücü ve kaynaklarıyla yürütmekte olduğu bir hizmeti ya da fonksiyonu daha verimli ve kaliteli hizmet sunmak, diş tedarikçilerin sahip olduğu hizmete özel uzmanlıktan faydalanmak, kendi temel yeteneklerine daha fazla odaklanmak gibi pek çok gerekçeyle, yasal bir sözleşme çerçevesinde üçüncü taraf bir dış tedarikçiye devretmesidir $\mathrm{Bu}$ devrediş bir hizmetin ya da fonksiyonun tüm bileşenleriyle devredilmesi şeklinde büyük bir ölçekte gerçekleşebileceği gibi, belirli unsurların oldukça kısıtlı biçimde dıș tedarikçilere bırakılması şeklinde de seyredebilir. Buradaki önemli nokta tedarikçinin ne kümesteki tilki gibi denetimsiz özgürlüğe sahip olması ne de yanaşık düzen eğitimi gören bir er gibi katı disipline maruz kalmasıdır. Her örgüt tipine uyan ideal bir DKY stratejisi olmadığı gerçeği göz önüne alındığında, her örgütün farklı ölçeklerde DKY'ye yer vermesi şaşırtıcı olmamalıdır.

Bu noktada sağlık hizmeti örgütlerini çözüm arayışlarına iten sürecin gelişimi de göz önüne alınmalıdır. Daha önce de bahsi geçen 50 - 60 yıllık dönem içerisinde başvurulan tüm maliyet artış1 önleme stratejileri ve yasal düzenlemelere rağmen, sağlık hizmetlerine yapılan harcamalar olağanüstü bir hızla yükselmeye devam etmiştir. Söz konusu girişimlerin ilk uygulayıcılarından olan ABD'de bile sağlık harcamaları diğer gelişmiş ülkelerdekilere kıyasla üç mislinden fazla artmıştır (Bristol, 2005). 
Maliyetleri kontrol altında tutma yönündeki tüm çabalarına rağmen sağlık kuruluşları halen artan maliyet baskıları ile karşı karşıyadır. Farklı hızlarda seyretse de sağlık hizmetlerine yapılan harcamalardaki artış küresel bir eğilim göstermektedir. Hastane harcamalarındaki bu artışı pek çok nedenle ilişkilendirmek mümkündür. Artan işgücü, malzeme vb. maliyetlere bağlı olarak artan hizmet fiyatları, genel anlamdaki nüfus artışı, talep edilen hizmetin miktar ve yoğunluğundaki artışlar, yaşlanan nüfus, hastane hizmetlerine dair enflasyonun genel ekonomik enflasyonu aşması, yeni ve pahalı teknolojilerin daha fazla kullanılmaya başlanması farklı çalışmalarda vurgulanan nedenler olarak dikkati çekmektedir (Diana, 2006; Levit, 2004; Shactmanve di ̌̆., 2003).

Maliyetlerdeki bu artışa ek olarak hastaneler bir yandan da şiddetini giderek daha fazla hissettiren bir rekabetle yüz yüze gelmiştir. Her ne kadar son on yılda hastanelerin başvurduğu rekabet silahları değişim göstermiş olsa da farklı kaynaklardan beslenen rekabetin yoğunluğu artmaya devam etmiştir.

Hastaneler bir yandan artan maliyetler ve önemli boyutlara ulaşan rekabetle uğraşırken, bir yandan da sundukları sağlık hizmetlerinin kalitesinin yükseltilmesi yönündeki baskılarla karşılaşmışlardır. Öyle ki geri ödeme ve akreditasyon konularının artık ciddi anlamda kalite ve güvenlikte gösterecekleri ilerlemelere bağlı hale getirilmesi mevzu bahistir. Tüm bu sorunlar karşısında hastane yöneticileri önemli bir araç olarak DKY'ye yönelmeyi tercih etmektedir.

Örgütlerin DKY'ye yönelmesinde, kendilerini rakiplerinden ayırt eden yetenek ve becerileri olan temel yeteneklerine odaklanmak, kısıtlı durumdaki kaynaklarını bu faaliyetler için sarf etmek istemeleri, bu kapsam dışında gördükleri işleri bir dış tedarikçiye yaptırmayı tercih etmeleri öncelikli rol oynayan faktördür. Örgütler kendilerine rekabet avantajı sağlayan bu temel yetenekleri dışındaki tüm işleri dış tedarikçilere yaptırarak hem kaynak tasarrufu yapmayı, hem yapı olarak küçülmeyi ve yalın hale gelmeyi, hem de kendilerinin iyi bildikleri işler üzerinde yoğunlaşma firsatı yakalamayı amaçlamaktadırlar (Koçel, 2010). Buna ek olarak artık örgütler DKY'ye açtıkları sınırları kendi temel yeteneklerine kadar genişletmişlerdir (Willcocks ve Curie, 1997; Roberts, 2001; Young, 2002, 2005; Billi ve diğ., 2004).

DKY'nin sağlık hizmetlerinin kalitesini ve hizmete erişimi artıran yönlerinin de olduğu öne sürülmektedir. Özellikle temel yetenekleri dışındaki faaliyetlerini dış tedarikçilere devreden hastaneler, temel yetenekleri olan sağlık hizmetlerinin kalitesini artırmaya odaklanabilmektedir. Hastanelerin dalgalanan talebi karşılamak üzere dışardan ilave hizmet alma yoluna gitmesi de sıkça rastlanan bir uygulamadır. Hastaneler aynı tercihi daha önce sunmadıkları hizmetler için de yapabilirler. Bu stratejiler hizmetin zamanında ve yerinde sunumunu sağlayarak hizmete erişimi artırabilir. DKY'nin bir başka özelliği olan uzman bilgi birikimine daha fazla erişimin de sağlık hizmetlerinin kalitesini artırmada önemli etkileri söz konusudur.

Sahip olduğu olumlu potansiyele rağmen, sağlık hizmetleri literatürü DKY hakkında pek çok dezavantajdan da bahsetmektedir. Bunlardan ilki maliyet tasarruflarının beklenenin altında gerçekleşebilmesi ve uzun vadede geçerliliğini yitirmesidir (Domberger ve Rimmer, 1994; Willcocks ve Currie, 1997; Roberts, 2001; Young ve Macneil, 2000; Macinati, 2008). İkincisi kamu sektöründeki hizmet sunucusu, hizmet sunum sürecinde elinde tuttuğu kontrolü önemli ölçüde yitirebilir ve kendini tedarikçiye gereğinden fazla bağlı biçimde ya da tedarikçinin faaliyetlerine güvenir halde bulabilir (Roberts, 2001; Billi ve diğ., 2004; Janssens ve Mohaghegh, 2005). Bu şartlar altında DKY'nin kaçınılmaz biçimde kamu sektöründeki hizmet sunucularının kendi amaçlarına ulaşma yeteneğini zayıflattığı da varsayılmaktadır (Roberts, 2001). Son olarak yetersiz sözleşme hükümleri ve sözleşme yönetimi veya seçilen tedarikçinin gerekli standartları karşılayamaması nedeniyle DKY'nin hizmet kalitesi üzerindeki etkileri bağlamında sorunlar da ortaya çıkabilmektedir.

Sağlık hizmetleri söz konusu olduğunda, hem profesyonelliğin daha keskin sınırlarla belirlenmiş olması hem de sağlık hizmetlerinin kendine has özellikleri DKY sorunsalını biraz daha karmaşık hale getirmektedir. Diğer sektörlere kıyasla sağlık hizmetlerinde karar süreçleri daima daha kritik, hatayı daha az kaldırabilen süreçler olmuştur. Aynı hassasiyet sağlık kuruluşlarına DKY'nin girişi için de söz konusudur. Günümüzde DKY'nin bir yerde hareket noktası olan temel yetenek yaklaşımının kendisine 
çizdiği sınırları zorlaması ve hatta bazı örgütlerde bu sınırları aşması, DKY için yeniden pek çok soru işaretini, endişeyi beraberinde getirmiştir.

Artık günümüzde DKY ile ilgili soruların boyutu "Evet mi? Hayır mı?” ölçeğini aşmış olsa da uygulamaya yönelik körü körüne bir kabul ya da reddediş durumu söz konusu olamamaktadır. $\mathrm{Bu}$ sorunun çıkış noktası, içinde bulunulan şartlarla, örgütlerin kendilerine has yapılarıyla ve özellikleriyle, iç ve dış işgücünün niteliği ve niceliğiyle ve bununla ilgili pek çok faktörle alakalıdır.

Unutulmamalıdır ki, DKY kendisi bizzat bir amaç veya son değildir. Örgütlerin kendileri için tayin ettikleri daha önemli amaçlar uğrunda kullanılabilecek önemli bir araç olduğu göz ardı edilmemelidir. Herhangi bir DKY uygulaması, bahsedilen bu daha üst hedeflere ulaşma sürecine katkıda bulunmuyorsa, 1srarcı olmak zaman ve kaynak israfının ötesine geçmeyecektir. Bu durumda yapılması doğru olan ise verimlilik, etkililik ve tasarruf gibi noktalara erişmenin alternatif yollarını aramaktır. Bu çalışmanın amacı, kavramsal olarak Dış Kaynaklardan Yararlanma'ya ve sağlık sektörüyle olan ilişkilerine değindikten sonra, kamu sektöründe DKY uygulamalarının üzerinde işlerlik kazandığı hukuki altyapıyı incelemek ve bu incelemeyi kamu alımlarına ait birtakım istatistiklerle desteklemektir.

\section{Türkiye'de DKY Uygulamalarının Yasal Altyapısı}

Türkiye'de kamu sektöründe girişilen DKY uygulamalarının yasal altyapısıyla ilgili olarak geriye doğru gidildiğinde, konuya yönelik olarak karşımıza çıkan ilk derli toplu yasa metni 1983 yılında yürürlüğe girmiş olan 2886 sayılı Devlet İhale Kanunu (DİK)'dur. 2886 sayılı DİK 01 Ocak 2003 tarihine kadar genel ve katma bütçeli kurumlar ile il, ilçe belediyeleri ve diğer yerel yönetimlerin her türlü ihale faaliyetlerini (tedarik, iş ve hizmet) kapsamıştır. Kamu iktisadi teşebbüsleri (KİT) veya diğer bazı özerk idareler DİK'a tabi olmamakla birlikte, işlemlerini adı geçen kanuna benzer hükümler taşıyan, kendilerine özgü yönetmeliklere göre yürütmüşlerdir. TC Sağlık Bakanlığı'na bağlı hastaneler de DKY uygulamalarını, ihtiyaçların en iyi şekilde, uygun şartlarda ve zamanında karşılanmasını amaçlayan, ihalelerde açıklık ve rekabetin sağlanmasını esas alan 2886 sayılı DİK'na göre gerçekleştirmişlerdir (Ergin, 2003).

DİK, 2003 yılının ilk günü itibariyle belirli süreçlerde yerini 04 Ocak 2002 tarihinde kabul edilen 4734 sayılı Kamu İhale Kanunu'na (KİK) bırakmıştır. Bu kanunun amacı, kamu hukukuna tabi olan veya kamunun denetimi altında bulunan veyahut kamu kaynăg 1 kullanan kamu kurum ve kuruluşlarının yapacakları ihalelerde uygulanacak esas ve usulleri belirlemektedir. KİK'nun bir gereği olarak saydamlığı, rekabeti, eşit muameleyi, güvenilirliği, gizliliği, kamuoyu denetimini, gereksinimlerin uygun koşullarla, zamanında karşılanması ve kaynakların verimli kullanılmasını sağlamakla yükümlü olan Kamu İhale Kurumu teşkil edilmiştir. 4734 sayılı Kanunun ilgili kısmında Kamu İhale Kurumu, bu kanunla verilen görevleri yapmak üzere kamu tüzel kişiliğine haiz, idari ve mali özerkliğe sahip bir yapıda tanımlanmıştır. Kamu İhale Kurumu, bu kanunda belirtilen esas, usul ve işlemlerin doğru biçimde uygulanması hususunda görevli ve yetkili kılınmıştır.

Merkezi Ankara'da yer alan kurum, TC Maliye Bakanlığı ile ilişkilidir. Görevini bağımsız şekilde yerine getirirken, herhangi bir organ, makam, merci ve kişinin, kurumun kararlarını etkilemek amacıyla emir ve talimat vermesi kanun hükümlerince yasaklanmıştır. Kamu İhale Kurulu, Başkanlık ve hizmet birimlerinden oluşan Kurumun görev ve yetkileri ilgili kanun metninde şöyle sıralanmıştır:

- İhalenin başlangıcından sözleşmenin imzalanmasına kadar olan süre içerisinde idarece yapılan işlemlerde bu Kanun ve ilgili mevzuat hükümlerine uygun olmadığına ilişkin şikâyetleri inceleyerek sonuçlandırmak,

- 4734 ve 4735 sayılı Kanunlara ilişkin bütün mevzuatı, standart ihale dokümanlarını ve tip sözleşmeleri hazırlamak, geliştirmek ve uygulamayı yönlendirmek,

- İhale mevzuatı ile ilgili eğitim vermek, ulusal ve uluslararası koordinasyonu sağlamak,

- Yapılan ihaleler ve sözleşmelerle ilgili Kurum tarafından belirlenen şekilde bilgi toplamak, adet, tutar ve diğer konular itibariyle istatistikler oluşturmak ve yayımlamak, 
- Haklarında ihalelere katılmaktan yasaklama kararı verilenlerin sicillerini tutmak,

- Araştırma ve geliştirme faaliyetlerinde bulunmak,

- İhale ilanları ile ilgili esas ve usulleri düzenlemek, basılı veya elektronik ortamda Kamu İhale Bültenini yayımlamak,

- Yerli isteklilerin, yabanc1 ülkelerde açllan ihalelere katılımlarına engel olunduğunun tespit edilmesi halinde, bu uygulamanın yapıldığı ülkenin isteklilerinin de, bu Kanun kapsamında yapılan ihalelere katılmalarının önlenmesine yönelik tedbirlerin alınmasını ve gerekli düzenlemelerin yapılmasını sağlamak üzere Bakanlar Kuruluna teklifte bulunmak,

- Kurumun yıllık bütçesi ile kesin hesabını ve yıllık çalışma raporlarını hazırlamak, Kurum bütçesinin uygulanmasını, gelirlerin toplanmasını ve giderlerin yapılmasını sağlamaktır.

KİK'a göre yapılacak ihalelere ilişkin sözleşmelerin düzenlenmesi ve uygulanması ile ilgili esas ve usuller 05 Ocak 2002 tarihinde kabul edilen 4735 sayılı Kamu İhale Sözleşmeleri Kanunu (KİSK) ile belirlenmiş̧ir. Bu kanun ihaleler neticesinde düzenlenen sözleşmeleri kapsamaktadır. KİK ve KİSK vücut bulduğu her aşamada, başta TC Anayasası olmak üzere birçok kanundan esinlenmiş ve dayanak noktası oluşturmuştur. Kanun, sözleşmenin oluşturulduğu ve onaylandıktan sonraki uygulamalarda idarenin yapacağı her türlü keyfiyetten şahısları koruyacak hükümler içermektedir. Bunlar asli ve tali koruma olarak isimlendirilebilir. Bu koruma ile kamu ihale sözleşmeleri, Türk hukuk yapısı içerisinde ayrı bir yere sahiptir. Tablo 1'de kamu ihaleleri sözleşmelerinde hukuk hiyerarşisi özetlenmiştir.

Tablo 1:Kamu İhaleleri Sözleşmelerinde Hukuk Hiyerarşisi

\begin{tabular}{|c|c|c|c|c|c|c|c|}
\hline \multicolumn{8}{|c|}{ T.C. ANAYASASI } \\
\hline \multirow{11}{*}{ 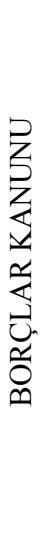 } & \multirow{11}{*}{ 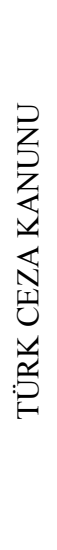 } & \multirow{7}{*}{ 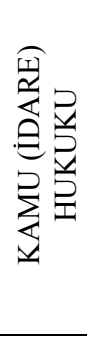 } & \multirow{11}{*}{ 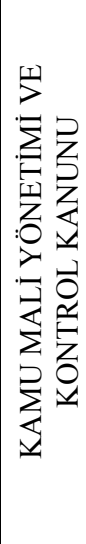 } & \multirow{7}{*}{$\stackrel{\mathscr{V}}{ }$} & Hizmet Alımı İhaleleri Uygulama Yönetmeliği & \multirow{11}{*}{ 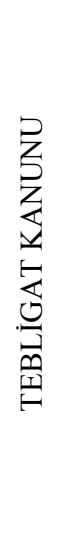 } & \multirow{11}{*}{ 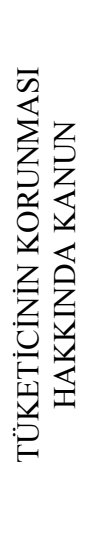 } \\
\hline & & & & & Mal Alımı İhaleleri Uygulama Yönetmeliği & & \\
\hline & & & & & Yapım İşleri İhaleleri Uygulama Yönetmeliği & & \\
\hline & & & & & Danışmanlık Hizmet Alımı İhaleleri Uygulama Yönetmeliği & & \\
\hline & & & & & Çerçeve Anlaşma İhaleleri Uygulama Yönetmeliği & & \\
\hline & & & & & Kamu İhale Genel Tebliği & & \\
\hline & & & & & $\begin{array}{l}\text { İhalelere Yönelik Başvurular Hakkında Yönetmelik ve } \\
\text { Tebliğ }\end{array}$ & & \\
\hline & & & & & $\begin{array}{l}\text { Malı Alımları Denetim Muayene ve Kabul İşlemlerine Dair } \\
\text { Yönetmelik }\end{array}$ & & \\
\hline & & 鹀 & & $\frac{v}{\mathscr{N}}$ & Hizmet Alımları Muayene ve Kabul Yönetmeliği & & \\
\hline & & : 0 光 & & $\ddot{-1}$ & Yapım İşleri Muayene ve Kabul Yönetmeliği & & \\
\hline & & & & & $\begin{array}{l}\text { Danışmanlık ve Hizmet Alımları Muayene ve Kabul } \\
\text { Yönetmeliği }\end{array}$ & & \\
\hline
\end{tabular}

Kaynak: Kılıç, D. 2010. Açıklama ve Emsal Kararlarla Kamu Alımları İhale ve Sözleşmeleri, Adalet Yayinevi.

4734 sayılı KİK ve 4735 sayılı KİSK'nin yürürlüğe girmesindeki temel nedenler şöyle sıralanabilir (Kılıç, 2010):

- Kamu harcaması gerektiren işler ile gelir elde edilmesine yönelik ihalelerin ihtiyaçlara cevap verecek şekilde ayrı kanunlarda düzenlenmesi gerekliliği,

- İhale mevzuatının Avrupa Birliği ve Dünya Ticaret Örgütü gibi uluslararası kuruluşların ihale mevzuatına paralel hale getirilebilmesi,

- 1999 Marmara depremi felaketinde, kamu binalarında oluşan zararın kamu vicdanındaki kötü imajının silinebilmesi için açılık ve rekabet olgusunun kamu ihalelerinde yeniden gözden geçirilmesi. 


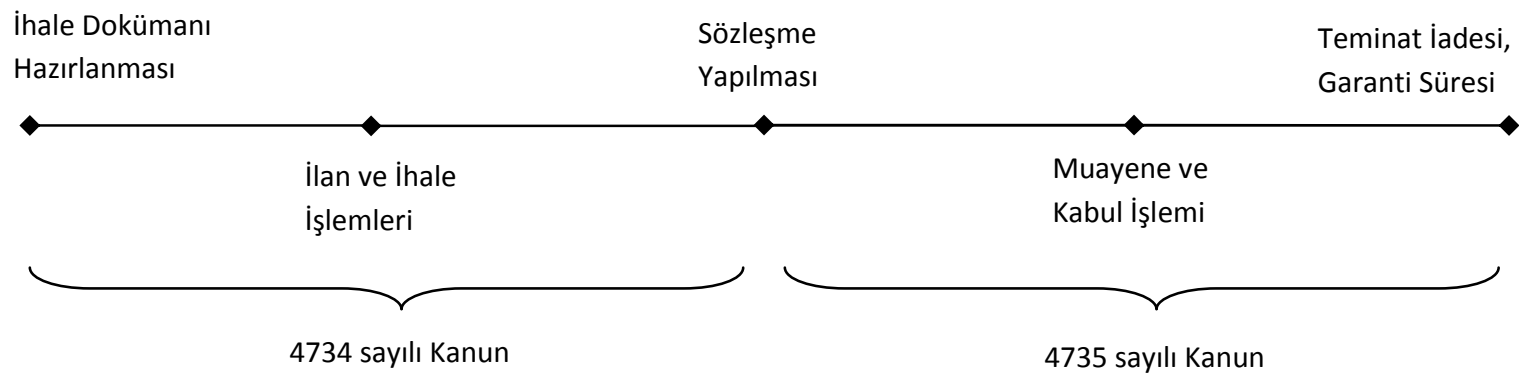

Şekil 1:Tedarik sürecinde 4734 ve 4735 sayılı Kanunların İlişkisi

Kaynak: Kılıç, D. 2010. Açıklama ve Emsal Kararlarla Kamu Alımları İhale ve Sözleşmeleri, Adalet Yayınevi.

Her iki kanun ile ulaş1lmak istenen hedef daha önce de ifade edildiği üzere kamu kurum ve kuruluşlarına ait idarelerin yapacağı alımlarda saydamlığı, rekabeti, eşit muameleyi, kamuoyu denetimini, kaynakların uygun harcanmasını sağlayacak şekilde sözleşme yapılması olmakla birlikte, kapsadıkları alanlar farklıdır. 4734 sayılı KİK, idarelerin ihtiyaçlarının belirlenip, ihale dokümanının hazırlanması ile başlayıp ihale yapılarak sözleşme imzalanmasına kadar olan süreci kapsamaktadır. 4735 sayılı KİSK ise, idarenin sözleşme yapmasından, yüklenicinin edimini ifa ederek teminatının çözülmesine kadar olan sürece yönelik hükümler içermektedir. İki kanun metni arasındaki ilişki Şekil 1'de görülmektedir.

Tablo 2: KİK ve KİSK'nun kapsam1

\begin{tabular}{|l|l|}
\hline \multicolumn{1}{|c|}{\begin{tabular}{c}
\multicolumn{1}{|c|}{ Kanun Kapsamındaki İdareler } \\
ve Uygulanacak İhaleler
\end{tabular}} & \multicolumn{1}{c|}{ Kanun Kapsamı Dışındaki İdareler } \\
\hline $\begin{array}{l}\text { Genel bütçe kapsamındaki kamu idareleri, özel bütçeli } \\
\text { idareler, il özel idareleri, belediyeler, bunlara bağlı } \\
\text { döner sermayeli kuruluşlar, birlikler. }\end{array}$ & Meslek kuruluşları ve bunların üst kuruluşları \\
\hline $\begin{array}{l}\text { Kamu iktisadi kuruluşları ile iktisadi devlet } \\
\text { teşekküllerinden oluşan kamu iktisadi teşebbüsleri. }\end{array}$ & Vakıf yükseköğretim kurumları \\
\hline $\begin{array}{l}\text { Sosyal güvenlik kuruluşları, fonlar, özel kanunlarla } \\
\text { kurulmuş ve kendisine kamu görevi verilmiş tüzel } \\
\text { kişiliğe sahip kuruluşlar, bağımsız bütçeli kuruluşlar. }\end{array}$ & $\begin{array}{l}\text { Tasarruf Mevduatı Sigorta Fonu ve bu Fonun hisselerine } \\
\text { kismen ya da tamamen sahip olduğu bankalar, 4603 } \\
\text { sayılı Kanun kapsamındaki bankalar (yapım ihaleleri } \\
\text { hariç) }\end{array}$ \\
\hline $\begin{array}{l}\text { 4603 sayılı Kanun kapsamındaki bankaların yapım } \\
\text { ihaleleridir. }\end{array}$ & $\begin{array}{l}\text { Enerji, su, ulaştırma ve telekomünikasyon sektörlerinde } \\
\text { faaliyet gösteren teşebbüs, şirket ve işletmeler }\end{array}$ \\
\hline
\end{tabular}

Kaynak: Kılıç, D. 2010. Açıklama ve Emsal Kararlarla Kamu Alımları İhale ve Sözleşmeleri, Adalet Yayınevi.

4734 sayılı KİK ve 4735 sayılı KİSK; 2886 sayılı DİK’yi yürürlükten kaldırmamıştır. Alım, hizmet, yapım, kiralama ve taşıma işleri kamu kaynağının harcanmasını gerektiren ihale sözleşmeleri 4734 sayılı KİK ve 4735 sayılı KİSK hükümlerine uygun olarak yapılır. 2886 sayılı DİK ise satım, kiraya verme, mülkiyetin gayri ayni hak tesisi işleri gibi kamuya gelir getirici ihale ve sözleşmelerde uygulanmaktadır. 
4734 say1l Kanunun 68/a maddesi "Bu kanun kapsamında yer alan işlerin ihalelerinde 8.9.1983 tarihli 2886 sayılı Devlet İhale Kanunu hükümleri uygulanmaz." ifadesiyle, 4734 say1lı Kanun kapsamı dışındaki satım, kiraya verme, trampa ve mülkiyetin gayri ayni hak tesisi işlerinin 2886 sayılı DİK hükümlerine göre yürütüleceğini belirlemiştir (K1lıç, 2010). Tablo 2'de kamu ihale ve sözleşmelerinin kapsamı ile ilgili bilgiler özetlenmiştir.

\section{İhale Süreci}

Çalışmanın bu kısmında T.C. Kamu İhale Kurumu tarafından yürürlükte bulunan kamu ihale mevzuatı esas alınarak 2010 yılında hazırlanan Hizmet Alımı Kılavuzu'yla çerçevesi çizilen ihale süreci hakkında bilgi verilecektir.

\section{İhtiyacın Ortaya Çıkması}

Hizmet alımı ihalelerinin ilk adımı ihtiyacın ortaya çıkışıdır. Kurum içerisinde ilgili birimler işleyişleri içerisinde oluşan gereksinimlerine yönelik taleplerini görevli birime iletirler. $\mathrm{Bu}$ sürecin 4734 sayılı KİK ile özellikle altı çizilmiş bir takım zorunlulukları vardır. İçlerinde belki de en önemlisi ödeneği bulunmayan hiçbir iş için ihaleye çıkılamayacağı hükmünü taşıyan maddedir. İlgili kanun ancak ertesi mali yılda gerçekleştirilecek süreklilik arz eden hizmet alımları için bir önceki mali yıl sona ermeden ihaleye çııılabileceğini ifade etmektedir.

İdare, bir sonraki yıla geçen veya bir yıldan daha uzun süreli olarak gelecek yıllara yaygın yüklenmelerini tâbi oldukları mali mevzuat ile ilgili diğer mevzuatı esas almak durumundadır. Bir yıldan daha uzun bir zaman dilimini kapsayan işlerde ihaleye çıkılabilmesi için, işin süresine uygun olarak yıllar itibariyle öngörülen ödeneğin bütçede yer almasını sağlamak üzere gerekli programın yapılmış olması zorunludur.

\section{Teknik Şartnamenin Hazırlanması}

İdare tarafından hizmet alımı ihalelerinde alıma konu olan hizmetin teknik kriterlerinin ve özelliklerinin belirtildiği teknik şartnamenin hazırlanması zorunludur. Teknik şartnamenin idare tarafından hazırlanması esastır. Ancak alınacak hizmetin özelliği itibariyle idarenin bu konuda yeterliliğinin olmadığı durumlarda, ihale yetkisinin de onaylaması şartıyla teknik şartname, ilgili kanun hükümlerine uygun olarak danışmanlık hizmeti bağlamında hazırlattırılabilir.

Teknik şartnamenin hazırlanmasında, 4734 sayılı Kanunun 12. maddesi ve Hizmet Alımı İhale Uygulama Yönetmeliğinin 16. maddesi ile hizmete ilişkin teknik mevzuatın hazırlanması ve uygulanmasına dair hükümler göz önünde bulundurulmalıdır. Teknik şartnamede düzenlemeler açık bir şekilde yapılmalıdır. Alım konusu hizmete ilişkin yetkili kurum düzenlemeleri mevcut ise bu düzenlemeler de dikkate alınmalıdır. Teknik kriterlerin ve özelliklerin, verimliliği ve işlevselliği sağlamaya yönelik olması, rekabeti engelleyici unsurlar içermemesi ve firsat eşitliğini sağlaması zorunludur.

Teknik şartnamede aday veya isteklinin ihaleye katılımda teknik yeterliliğine ilişkin sunacağ belgelere yönelik düzenleme yapılması durumunda bu belge veya belgelere ön yeterlik şartnamesinin "Ön yeterlik başvurusu için gereken belgeler ve yeterlik kriterleri" başlıklı maddesinin ilgili alt maddesinde veya idari şartnamenin "İhaleye katılabilmek için gereken belgeler ve yeterlik kriterleri" başlıklı maddesinin ilgili alt maddesine yer verilmesi gereklidir. Teknik şartnamede yapılan düzenleme ile ön yeterlik şartnamesi ve/veya idari şartnamede yapılan düzenlemelerin birbiriyle uyumlu olmas1 gerekmektedir.

\section{Yaklaşık Maliyetin Hesaplanması}

İdare tarafindan, ihale onay belgesi düzenlenmeden önce Hizmet Alımı İhaleleri Uygulama Yönetmeliğinde $(7,8,9$ ve 10. maddeler) belirlenen esas usullere göre ihale konusu hizmetin KDV hariç olmak üzere yaklaşık maliyeti hesaplanır ve dayanaklarıyla birlikte bir hesap cetvelinde ortaya 
konulur. Yaklaşık maliyetin hesaplanmasında başvurulan her türlü bilgi ve belgeye hesap cetveli ekinde yer verilir. Değerlendirmeye alınmayan fiyat bildirimleri ile proforma faturaların değerlendirmeye alınmama gerekçeleri de hesap cetvelinde ifade edilir.

Teknik şartnamenin hazırlanmasında olduğu gibi yaklaşık maliyetin de idarece hesaplanması esastır. Ancak, işin özelliğinden dolayı teknik şartnamenin danışmanlık hizmeti alınarak hazırlatılması durumunda, bu kapsamda yaklaşık maliyet de aynı danışmanlık hizmeti sunucusuna hesaplatılabilir. Teknik şartnamenin idare tarafından hazırlandığı bir ihalede yaklaşık maliyetin danışmanlık hizmeti alınarak hesaplatılması mümkün değildir.

Eğer ön ilan yayımlanacak ise tahmini alım miktarı esas alınarak yaklaşık maliyet hesaplanır. Ön ilanın yayımlanması sırasında tahmini alım miktarı esas alınarak hesaplanan yaklaşık maliyet, ihale veya ön yeterlik ilanı öncesi alım miktarı ve diğer hususlar göz önünde bulundurularak yeniden hesaplanabilir.

\section{İhale Usulünün Tespiti}

İdare tarafından 4734 sayılı Kanunun 18, 19, 20 ve 21. maddelerindeki hükümler doğrultusunda, uygulanacak ihale usulü belirlenir. Adı geçen kanun hükümlerine göre, idarelerce uygulanması öngörülen ihale usulleri açık ihale usulü, belli istekliler arasında ihale usulü ve pazarlık usulüdür.

Açık ihale usulü, bütün isteklilerin teklifi verebildiği usuldür. Belli istekliler arasında ihale usulünde, yapılacak ön yeterlik değerlendirmesi sonucunda idarece davet edilen isteklilerin teklif vermesi söz konusudur. Ön yeterlik dokümanı ve ön yeterlik ilanında belirtilen değerlendirme kriterlerine göre adayların ön yeterlik değerlendirmesi yapılır. Belirtilen asgari yeterlik koşullarını sağlayamayanlar yeterli kabul edilmez. Ön yeterlik ilanında ve dokümanında belirtilmek kaydıyla; yeterlikleri tespit edilenler arasından dokümanda belirtilen kriterlere göre sıralanarak listeye alınan belli sayıda istekli veya yeterli bulunan isteklilerin tamamı teklif vermeye davet edilebilir.

4734 say1lı Kanunun yine aynı maddesine göre, teklif vermeye davet edilmeyenlere gerekçesi yazılı olarak bildirilir. İşin niteliğine göre rekabeti engellemeyecek şekilde kanunun ilgili hükümleri doğrultusunda belirlenen ve ihale dokümanında ifade edilen değerlendirme kriterlerine göre tekliflerin değerlendirilmesi yapılarak ihale sonuçlandırılır. İhaleye davet edilebilecek aday sayısını beșten az olması veya teklif veren istekli sayısının üçten az olması ihale iptal sebebidir. Teklif veren istekli sayısının üçten az olması nedeniyle ihalenin iptal edilmesi durumu ile karşılaşılması halinde, ihale dokümanı hatalı olma durumuna karşı gözden geçirilir, eksikliklerin giderilmesinin ardından, ön yeterliği tespit edilen bütün istekliler yeniden davet edilerek ihale sonuçlandırılabilir.

4734 say1lı Kanunun 21. maddesinde pazarlık usulüne şu hallerde başvurulabileceği ifade edilmiştir:

- Açık ihale usulü veya belli istekliler arasında ihale usulü yapılan ihale sonucunda teklif çıkmaması durumunda,

- Doğal afetler, salgın hastalıklar, can veya mal kaybı tehlikesi gibi ani ve beklenmeyen veya idare tarafından önceden öngörülemeyen olayların ortaya çıkması üzerine ihalenin acilen yapılma zorunluluğunun doğması durumunda,

- Savunma ve güvenlikle ilgili özel durumların ortaya çıkması üzerine ihalenin acilen yapılma zorunluluğunun doğması durumunda,

- İhalenin, araştırma ve geliştirme sürecine ihtiyaç gösteren ve seri üretime konu olmayan nitelikte olması halinde,

- İhale konusu mal veya hizmet alımları ile yapım işlerinin özgün nitelikte ve karmaşık olması nedeniyle teknik ve mali özelliklerinin gerekli olan netlikte belirlenememesi koşulunda,

- İdarelerin yaklaş1k maliyeti 144.103 Türk Lirasına (Кати İhale Kurumu'nun 2012/1 sayılı Tebliği ile 24/1/2012 tarihli ve 28183 sayll Resmi Gazete'de yayınlanmış olup 01.02.2012 31.01.2013 dönemini kapsamaktadır) kadar olan mamul mal, malzeme veya hizmet alımlarında pazarlık usulü ihaleye başvurulabilmektedir. 


\section{İhale ve Ön Yeterlik Dokümanlarının Hazırlanması}

İhale ve ön yeterlik dokümanının hazırlanmasında, Hizmet Alımı İhaleleri Uygulama Yönetmeliği’nin "Genel Hükümler” başlıklı Birinci Kısmının "İhale Usulünün Tespiti, İhale ve Ön Yeterlik Dokümanı" başlıklı Üçüncü Bölümü ile Kamu İhale Genel Tebliğinin "Dokümana İlişkin Hususlar" başlıklı 15. maddesi esas alınmalıdır. Ayrıca ekonomik ve mali yeterlik ile mesleki ve teknik yeterliğin belirlenmesi mevzuatın ilgili hükümleri çerçevesinde yapılmalıdır.

İdare tarafından ihale ve/veya ön yeterlik dokümanının hazırlanmasında, Hizmet Alım İhaleleri Uygulama Yönetmeliği ekinde yer alan tip şartnameler, standart formlar, tip sözleşme ve Kurum tarafından yayımlanan diğer mevzuat esas alınmaktadır. İhale dokümanı şu belgelerden oluşur:

- İdari Şartname / Ön Yeterlik Şartnamesi,

- Teknik Şartname,

- Sözleşme Tasarısı,

- Standart Formlar,

- İdare ihale dokümanı kapsamında verilecek diğer belgeler.

İdari şartname, idare tarafindan uygulanacak ihale usulüne ilişkin olarak Hizmet Alım Uygulama Yönetmeliği ekinde yer alan tip şartname esas alınarak hazırlanır. Tip idari şartnamede boş bırakılan veya dipnota alınan hususlar; işin özelliğine göre, 4734 sayılı Kanun, 5/1/2002 tarihli ve 4735 sayılı KISSK ve diğer mevzuat hükümlerine aykırı olmayacak şekilde düzenlenir.

İdare, tip idari şartnamede düzenlenmeyen ancak işin özelliğine göre düzenlenmesine gerek duyulan hususları, 4734 ve 4735 sayılı Kanunlar ile diğer mevzuat hükümlerine aykırı olmamak koşuluyla, maddeler halinde düzenleyerek "Diğer Hususlar" bölümüne ekleyebilir. İdare, belli istekliler arasında ihale usulü ile yapacağı ihalede, ön yeterlik şartnamesini, bu tip ön yeterlik şartnamesini esas alarak hazırlar. Tip ön yeterlik şartnamesinde boş bırakılan veya dipnota alınan hususlar; işin özelliğine göre, 4734 sayılı Kanun, 5/1/2002 tarihli ve 4735 sayılı KİSK ve diğer mevzuat hükümlerine aykırı olmayacak şekilde düzenlenir.

Belli istekliler arasında ihale usulü ile yapılacak ihalelerin ön yeterlik dokümanında; adaylarda aranılan şartlara, ön yeterlik kriterlerine ve gerekli diğer belge ve bilgilere yer verilir. Ayrıca, yeterlikleri tespit edilenler arasından belli sayıda adayın ihaleye davet edilmesinin öngörüldüğü durumlarda, sıralama kriterleri ve puanlama yöntemi ile beşten az olmamak üzere listeye alınacak aday sayısı da ön yeterlik dokümanında belirtilir.

Alınacak hizmetin teknik kriterlerinin ve özelliklerinin, ihale dokümanının bir parçası olan teknik şartnamede düzenlenmesi zorunludur. Teknik kriterlerin ve özelliklerin, verimliliği ve fonksiyonelliği sağlamaya yönelik olması, rekabeti engelleyici hususlar içermemesi ve firsat eşitliğini sağlaması zorunludur.

İdare, sözleşme tasarısını, tip sözleşmeyi esas alarak hazırlar. Tip sözleşmede boş bırakılan veya dipnota alınan hususlar; işin özelliğine ve sözleşme türüne (götürü bedel / birim fiyat) göre 4734 ve 4735 sayılı Kanunlar ile diğer mevzuat hükümlerine aykırı olmayacak şekilde düzenlenir. İhalelerde, Kamu İhale Kurumu'nun uygun görüşü alınmak kaydıyla istekliler tarafından hazırlanması mutat olan sözleşmeler kullanılabilir.

\section{İhale Onayının Alınması}

İhale onayının alınması, Hizmet Alımı İhaleleri Uygulama Yönetmeliğinin 18. maddesinde düzenlenmiştir. Adı geçen Yönetmeliğin ilgili maddesine göre, ihale konusu işe ilişkin yaklaşık maliyet hesap cetveli, şartnameler, sözleşme tasarısı ve diğer doküman ihale onay belgesine eklenir ve bu belge ihale yetkilisinin onayına sunulur.

Ön ilan yapılması durumunda, bu ilandan önce ihale onay belgesi ihale yetkilisinin onayına sunulur. $\mathrm{Bu}$ belgeye sadece yaklaşık maliyet hesap cetvelinin eklenmesi yeterlidir. İhale veya ön 
yeterlik ilanı yayımlanmadan önce, yeniden ihale onay belgesi hazırlanarak ihale yetkilisinin onayına sunulur. Ön ilan, ihale ilanı veya ön yeterlik ilanı yayımlanmadan, ilan yapılmaksızın gerçekleştirilen ihalelerde ise davet yazısı gönderilmeden önce Kamu İhale Kurumu'ndan ihale kayıt numarası alınır.

\section{İhale Komisyonunun Kurulması ve Çalışma Esasları}

İhale yetkilisi, ihaleyi gerçekleştirmek üzere 4734 sayılı Kanun'un 6. maddesi ile Hizmet Alımı İhaleleri Uygulama Yönetmeliğinin 19. maddesi gereğince, ihale ilanı veya ön yeterlik ilanı ya da davet tarihini izleyen en geç üç gün içerisinde ihale komisyonu oluşturulur. İhale komisyonunun yapısı Kamu İhale Genel Tebliğinin 5. maddesinde ayrıntılı biçimde açıklanmıştır.

İhale komisyonu, toplamda tek sayı olmak üzere başkan dahil en az beş kişiden oluşur. Üyelerden en az ikisinin ihaleye konu olan işin uzmanı ve diğer bir üyenin muhasebe veya mali işlerden sorumlu personel olması zorunludur. İhale komisyonunun görevlendirilmesi esnasında komisyonun eksiksiz toplanacağı dikkate alınarak, asıl üyeler ile bu üyelerin yerine geçecek aynı vasıflara sahip yeterli sayıda yedek üyenin isimleri ve bu üyelerin komisyonda hangi sıfatla yer alacakları belirtilir. $\mathrm{Bu}$ çerçevede yedek üyeler tespit edilirken ihale konusu işin uzmanları ile muhasebe veya mali işlerden sorumlu personel yerine geçecek yedek üyeler de bu niteliklere sahip personel içerisinden seçilmelidir.

İhale komisyonu eksiksiz olarak toplanır ve kararlar çoğunluk esasıyla alınır. Komisyon üyelerinin kararlarında çekimser kalma şansları yoktur. Komisyon başkanı ve üyeleri oy ve kararlarından sorumlu olup; karşı oy kullanan komisyon üyeleri, gerekçelerini komisyon kararına yazmak ve imzalamak zorundadırlar. İhale komisyonunca alınan kararlar ve düzenlenen tutanaklar, komisyon başkanı ve üyelerinin isim, unvan ve komisyondaki sıfatlarına dair bilgiler belirtilerek imza altına alınır.

\section{İlan}

İhalelere katılacak isteklilere davet niteliğinde olan ilanlarda gerekli bilgilerin edinilmesine olanak sağlamak amaciyla, ihaleye konu işi tanımlayacak hususlar ile isteklilerin yeterliğinin tespiti için istenen belgelere ilişkin bilgiler belirtilmektedir.4734 say1lı Kanunun 62. maddesinin (f) bendiyle, ihale dokümanı yapılmaksızın ilana çıkılması yasaklanmıştır. İlan sürelerinin hesaplanmasında, ilanın yayın tarihi esas alınır, ihale günü ve son başvuru günü dikkate alınmaz. İlgili maddede belirtilen ilan sürelerine uyarak, ilan yapılmasına kadar geçecek süre de göz önüne alınarak ilan yapılacak yerlere yeterli bir süre önceden ilan metinlerinin gönderilmesi zorunludur. İhale ilan sürelerine ilişkin düzenlemeler 4734 sayılı Kanunun 13. maddesinde yer almaktadır.

\section{Başvuruların veya Tekliflerin Alınması ve Değerlendirilmesi ile İhalenin Karara Bağlanması}

Başvuru ve tekliflerin alınması, açılması ve değerlendirilmesi ile karara bağlanmasında 4734 sayılı Kanunun İkinci Kısım Dördüncü Bölümü $(36,37,38$, 39 ve 40. maddeler), Hizmet Alımı İhaleleri Uygulama Yönetmeliğinin Üçüncü Kısım İkinci Bölümü (56, 57, 58 ve 59. maddeler), ile ön yeterlik şartnamesi ile idari şartnamelerin "Tekliflerin Değerlendirilmesi ve Sözleşme Yapılmasına İlişkin Hususlar" bölümündeki düzenlemeler esas alınır.

4734 sayılı Kanunun 36. maddesinde, ihale anına kadar verilen tekliflerin tespit edilmesi, duyurulması, ihaleye başlanması, teklif zarflarının açılması, uygun olmayanların değerlendirme dışı bırakılması, açılan tekliflerin kontrolü ve tekliflerin değerlendirilmek üzere ihale komisyonuna devrine dair hükümler yer almaktadır. 37. madde ise 36. madde hükümlerine göre uygun görülen teklifler üzerinde yapılabilecek değişikliklerden ve bu değişikliklerin içeriklerinden bahsedilmektedir. Ayrıntılı değerlendirme sürecinden bu maddede bahsedilir. Bu aşamada, isteklilerin ihale konusu işi yapabilme kapasitelerini belirleyen yeterlik kriterlerine ve tekliflerin ihale dokümanında belirtilen şartlara uygun olup olmadığ olmadığı belirlenen isteklilerin teklifleri değerlendirme dışı bırakılır. 
4734 sayılı Kanunun 38. maddesi ise aşırı düşük tekliflerle ilgilidir. İhale komisyonu verilen teklifleri 37. maddeye göre değerlendirdikten sonra, diğer tekliflere veya idarenin tespit ettiği yaklaşık maliyete göre teklif fiyatı aşırı düşük olanları tespit eder. Bu teklifleri reddetmeden önce, belirlediği süre içerisinde teklif sahiplerinden önemli gördüğü bileşenler ile ilgili ayrıntıları yazılı olarak talep eder.

Yine aynı madde gereğince ihale komisyonu; imalat sürecinin, verilen hizmetin ve yapım yönteminin ekonomik olması, seçilen teknik çözümler ve teklif sahibinin mal ve hizmetlerin temini veya yapımı işinin yerine getirilmesinde kullanacağı avantajlı koşullar, teklif edilen mal, hizmet veya yapım işinin özgünlüğü hususlarında belgelendirilmek suretiyle yapılan yazılı açıklamaları dikkate alarak, aşırı düşük teklifleri değerlendirir. Bu değerlendirme sonucunda, açıklamaları kâfi bulunmayan veya yazılı açıklamada bulunmayan isteklilerin teklifleri reddedilir.

Aynı maddenin ek fikrasına göre, ihale komisyonu aşırı düşük tekliflerin tespiti ve değerlendirilmesinde Kurum tarafindan belirlenen kriterleri esas alır. Kurum bu maddenin uygulanmasında; aşırı düşük tekliflerin tespiti, değerlendirilmesi ve ekonomik açıdan en avantajlı teklifin belirlenmesi amaciyla sınır değer veya sorgulama kriterleri ya da ortalamalar belirlemeye yetkilidir.

Bütün tekliflerin reddedilmesi ve ihalenin iptali ilgili hükümler 4734 say1lı Kanunun 39. maddesinde ele alınmıştır. Söz konusu madde ihale komisyonuna tüm teklifleri reddederek ihaleyi iptal edebilme serbestliği tanımıştır. İdare bütün tekliflerin reddi durumunda herhangi bir yükümlülük altına girmez fakat istekliler tarafından talep edilmesi halinde, ihalenin iptal gerekçelerini bildirmek durumundadir.

Kanunun 40. maddesinde ihalenin karara bağlanması ve onaylanması ile ilgilidir. Bu maddeye göre ihale daha önceki maddelerde belirtilen değerlendirme süreçlerinin ardından ekonomik açıdan en avantajlı teklifi veren isteklinin üzerinde bırakılır. Burada ekonomik açıdan en avantalı teklif ile sadece fiyat esasına göre veya fiyat ile birlikte işletme ve bakım maliyeti, maliyet etkililik, verimlilik, kalite ve teknik değer gibi fiyat dışındaki unsurlar da dikkate alınarak tayin edilmektedir. Ekonomik açıdan en avantajlı teklifin fiyat dışındaki unsurların da hesaba katılarak belirleneceği hallerde, ihale dokümanında bu unsurların parasal değerleri veya nispi ağırlıkları da ortaya konulur.

En düşük fiyatın ekonomik açıdan en avantajlı teklif olarak değerlendirildiği ihalelerde, birden fazla istekli tarafından aynı fiyatın teklif edilmesi ve bunların da ekonomik açıdan en avantajlı teklifler olduğunun anlaşılması halinde, daha önce belirtilen fiyat dışındaki unsurlar dikkate alınmak suretiyle ekonomik açıdan en avantajlı teklif belirlenir ve ihale sonuçlandırılır.

İhale komisyonu gerekçeli kararını belirleyerek, ihale yetkilisinin onayına sunar. Karar metinlerinde isteklerin tanıtıc bilgileri, teklif edilen bedeller, ihalenin tarihi ve hangi istekli üzerinde hangi gerekçelerle bırakıldığ izleyen en geç beş iş günü içinde ihale kararını onaylar veya açıkça ifade ederek ihaleyi iptal edebilir. Kararın onaylanması ihaleye geçerlilik kazandırır, iptali durumunda hükmü yoktur.

Hizmet Alımı İhaleleri Uygulama Yönetmeliği' nin ilgili 56, 57, 58 ve 59. maddelerinde ise, 4734 sayılı Kanunun ilgili hükümleriyle genel çerçevesi çizilen tekliflerin değerlendirilmesi ve karara bağlanması sürecine yönelik daha detaylı talimatlar yer almaktadır. Adı geçen maddeler, başvuruların ve tekliflerin alınması, açılması ve belgelerdeki bilgi eksikliklerinin tamamlatılması, başvuruların değerlendirilmesi, tekliflerin değerlendirilmesi ve aşırı düşük tekliflerle ilgili hususlar üzerinedir. Aynı yönetmeliğin 60 ile 69. maddesi arasındaki kısımda, ekonomik açıdan en avantajlı teklif ve ihalenin sonuçlandırılması, yerli istekliler lehine fiyat avantajı uygulanan ihalelerde ekonomik açıdan en avantajlı teklifin belirlenmesi, tekliflerin eşit olması, bütün tekliflerin reddedilmesi ve ihalenin iptali, ihalenin karara bağlanması ve onaylanması konularına yönelik düzenlemeler yer almaktadır. 


\section{İhale Sonucunun Bildirilmesi ve Sözleşmenin İmzalanması}

Kesinleşen ihale kararının bildirilmesi 4734 sayılı Kanunun 41. Maddesi ve Hizmet Alımı İhaleleri Uygulama Yönetmeliği'nin 66. maddesi ile idari şartnamelerin "Kesinleşen İhale Kararının Bildirilmesi" başlıklı maddelerindeki hükümler çerçevesinde yapılır. Kesinleşen ihale kararı, "Kesinleșen İhale Kararının Bildirilmesi Standart Form - KIK019.1/H" kullanılarak isteklilere bildirilir. İhalenin iptali durumunda ise "İhale İptal Kararının Bildirilmesi Forumu Standart Form KİK019.2/H" ile isteklilere bildirilir. İhalenin iptal sebebi, ihale komisyonu tarafindan bütün başvuruların / tekliflerin reddedilmesi ise bu durumun isteklilere veya adaylara duyurulmasında "Bütün Başvuruların veya Tekliflerin Reddedilmesi Sebebiyle İhalenin İptali Formu Standart Form KİK019.3/H" kullan1lır.

İhale sonucu onaylandığı tarihi izleyen üç günlük süre içinde, ihale üzerinde bırakılan dahil teklif veren tüm isteklilere duyurulur. İhale sonucunun bildiriminde, tekliflerin değerlendirmeye alınmama veya uygun bulunmama gerekçelerine de yer verilir. İhalenin iptali durumunda da isteklilere gerekçeleri ile bildirim yapılması zorunludur. İhale sonucunun tüm isteklilere bildiriminden itibaren; 4734 sayılı Kanunun 21. maddesinin (b) ve (c) bentlerine göre yapılan ihalelerde beş gün, diğer hallerde ise on gün geçmedikçe sözleşme imzalanması mümkün değildir.

\section{Sözleșmeye Davet}

Sözleşmeye davet işlemleri 4734 sayılı Kanunun 42. maddesi ve Hizmet Alımı İhaleleri Uygulama Yönetmeliği'nin 67. maddesi ile idari şartnamelerin "Sözleşmeye Davet" başliklı maddelerindeki hükümler çerçevesinde yürütülür. Sözleşmeye davet "Üzerine İhale Yapılan İsteklinin Sözleşmeye Davet Edilmesine İliş̧kin Form Standart Form - KİK020.0/H” kullanılarak gerçekleştirilir.

4734 sayılı Kanunun 41. maddesinde belirtilen sürenin bitimini (ihale sonucunun tüm isteklilere bildiriminden itibaren, 21. Maddenin (b) ve (c) bentlerine göre yapılan ihalelerde beş, diğer hallerde on gün); ön mali kontrolün yapılması gereken hallerde ise bu kontrolün tamamlandığı tarihi izleyen günden itibaren üç gün içinde, ihale üzerinde bırakılan istekli sözleşmeye davet edilir. Bu davet yazısında, tebliğ tarihini izleyen on gün içinde yasal yükümlülüklerini yerine getirmek suretiyle sözleşmeyi imzalaması gerektiği ilgili istekliye bildirilir.

İhale üzerinde bırakılan istekli, sözleşmeye davet yazısının bildirim tarihini izleyen on gün içinde, ihale tarihinde 4734 sayılı Kanunun 10. maddesinin dördüncü fikrasının (a), (b), (c), (d), (e) ve (g) bentlerinde sayılan durumlarda olmadığına dair belgeler ile kesin teminatı verip diğer yasal yükümlülüklerini yerine getirerek sözleşmeyi imzalamak zorundadır. 4734 sayılı Kanunun bahsi geçen maddesinde ifade edilen hükümlere göre isteklinin sözleşmeyi imzalamasına engel olacak durumlar şunlardır:

- İflas eden, tasfiye halinde olan, işleri mahkeme tarafindan yürütülen, konkordato ilan eden, işlerini askıya alan veya kendi ülkesindeki mevzuat hükümlerine göre benzer bir durumda olan,

- İflası ilan edilen, zorunlu tasfiye kararı verilen, alacaklılara karşı borçlarından dolayı mahkeme idaresi altında bulunan veya kendi ülkesindeki mevzuat hükümlerine göre benzer bir durumda olan,

- Türkiye'nin veya kendi ülkesinin mevzuat hükümleri uyarınca kesinleşmiş sosyal güvenlik prim borcu olan,

- Türkiye'nin veya kendi ülkesinin mevzuat hükümleri uyarınca kesinleşmiş vergi borcu olan,

- İhale tarihinden önceki beş yıl içinde, mesleki faaliyetlerinden dolayı yargı kararıyla hüküm giyen,

- İhale tarihi itibariyle, mevzuatı gereği kayıtlı olduğu oda tarafindan mesleki faaliyetten men edilmiş olan. 
Mücbir sebep halleri dışında ihale üzerinde bırakılan isteklinin, sözleşmeyi imzalaması durumunda, geçici teminatı gelir kaydedilerek, hakkında 4734 sayılı Kanunun 58. maddesindeki hükümler uygulanır. Söz konusu maddeye göre, üzerine ihale yapıldığı halde mücbir sebep halleri dışında usulüne göre sözleşme yapmayanlar hakkında altı aydan az olmamak üzere bir yıla kadar, bütün kamu kurum ve kuruluşlarının ihalelerine katılmaktan yasaklama kararı verilir. Katılma yasakları, ihaleyi yapan bakanlık veya ilgili veya bağlı bulunulan bakanlık, herhangi bir bakanlığın ilgili veya bağlı kuruluşu sayılmayan idarelerde bu idarelerin yetkilileri, il özel idareleri ve belediyeler ile bunlara bağlı birlik, müessese ve işletmelerde ise İçişleri Bakanlığı tarafından verilir.

Sözleşmenin imzalanacağı tarihte, sözleşme imzalanmasından önce ihale sonuç bilgileri Kuruma gönderilmek suretiyle, ihale üzerinde kalan isteklinin ihalelere katılmaktan yasaklı olup olmadığının teyit edilmesi zorunludur.

İhale üzerinde bırakılan istekliyle sözleşme imzalanamaması durumunda, ekonomik açıdan en avantajlı ikinci teklif fiyatının ihale yetkilisi tarafından uygun bulunması şartıyla, bu teklif sahibi ile sözleşme yapılabilir. Ekonomik açıdan en avantajlı ikinci teklif sahibi istekli, 4734 sayılı Kanunun 42. maddesinde belirtilen sürenin bitimini izleyen üç gün içinde sözleşme imzalamaya davet edilir.

İdarenin sözleşme yapılması konusunda yükümlülüğünü yerine getirmemesi halinde istekli 4734 sayılı Kanunun 42. ve 44. maddelerinde belirtilen sürelerin bitimini izleyen günden itibaren en geç beş gün içinde, on gün süreli bir noter ihbarnamesi ile durumu idareye bildirerek taahhüdünden vazgeçebilir. $\mathrm{Bu}$ takdirde geçici teminat iade edileceği gibi istekli teminat vermek için yaptığı belgelendirilmiş giderlerini de talep edebilir.

Hizmet alım süreci içerisindeki ikili kanunî yapıda, sözleşme imzalanmasından sonraki süreçte 4735 sayılı KİSK'nin hükümleri ağırlıklı olarak geçerlidir. KİK'ye tabi kurum ve kuruluşlar tarafından söz konusu Kanun hükümlerine göre yapılan ihaleler sonucunda düzenlenen sözleşmeleri kapsayan Kanuna göre yapılan kamu sözleşmelerinin tarafları, sözleşme hükümlerinin uygulanmasında eşit hak ve yükümlülüklere sahiptir. İhale dokümanı ve sözleşme hükümlerinde bu prensibe aykırı maddelere yer verilemez.

4735 sayılı Kanunun 6. maddesinde KİK'ye göre düzenlenen ihaleler neticesinde düzenlenebilecek sözleşme türleri şöyle sıralanmıştır:

- Yapım işlerinde; uygulama projeleri ve bunlara ilişkin mahal listelerine dayalı olarak, işin tamamı için isteklinin teklif ettiği toplam bedel üzerinden anahtar teslimi götürü bedel sözleşme,

- Mal veya hizmet alımı işlerinde, ayrıntılı özellikleri ve miktarı idarece belirlenen işin tamamı için isteklinin teklif ettiği toplam bedel üzerinden götürü bedel sözleşme,

- Yapım işlerinde, ön veya kesin projelere ve bunlara ilişkin mahal listeleri ile birim fiyat tarifelerine, mal veya hizmet alımı işlerinde ise işin ayrıntılı özelliklerine dayalı olarak; idarece hazırlanmış cetvelde yer alan her bir iş kaleminin miktarı ile bu iş kalemleri için istekli tarafından teklif edilen birim fiyatların çarpımı sonucu bulunan toplam bedel üzerinden birim fiyat sözleşme,

- Yapım işlerinde; niteliği itibariyle iş kalemlerinin bir kısmı için anahtar teslimi götürü bedel, bir kısmı için birim fiyat teklifi alma yöntemleri birlikte uygulanmak suretiyle gerçekleştirilen ihaleler sonucunda karma sözleşme,

- Çerçeve anlaşmaya dayalı olarak idare ile yüklenici arasında imzalanan münferit sözleşme.

Yine aynı kanunun bir sonraki maddesiyle sözleşmelerde şu hususların belirtilmesi zorunlu kılınmıştır:

- İşin adı, niteliği, türü ve miktarı, hizmetlerde iş tanımı,

- İdarenin adı ve adresi, 
- Yüklenicini adı veya ticaret unvanı, tebligata esas adresi,

- Varsa alt yüklenicilere ilişkin bilgiler ve sorumlulukları,

- Sözleşmenin bedeli, türü ve süresi,

- Ödeme yeri ve şartlarıyla avans verilip verilmeyeceği, verilecekse şartları ve miktarı,

- Sözleşme konusu işler için ödenecekse fiyat farkının ne şekilde ödeneceği,

- Ulaşım, sigorta, vergi, resim ve harç giderlerinden hangisinin sözleşme bedeline dahil olacağ 1 ,

- Vergi, resim ve harçlar ile sözleşmeyle ilgili diğer giderlerin kimin tarafından ödeneceği,

- Montaj, işletmeye alma, eğitim, bakım - onarım, yedek parça gibi destek hizmetlerine ait şartlar,

- Kesin teminat miktarı ile kesin teminatın iadesine ait şartlar,

- Garanti istenilen hallerde süresi ve garantiye ilişkin şartlar,

- İşin yapilma yeri, teslim etme ve teslim alma şekil ve şartları,

- Gecikme halinde alınacak cezalar,

- Mücbir sebepler ve süre uzatımı verilebilme şartları, sözleşme kapsamında yaptırılacak iş artışları ile iş eksilişi durumunda karşılıklı yükümlülükler,

- Denetim, muayene ve kabul işlemlerine ilişkin şartlar,

- Yapım işlerinde iş ve işyerinin sigortalanması ile yapı denetimi ve sorumluluğuna ilişkin şartlar,

- Sözleşmede değişiklik yapılma şartları,

- Sözleşmenin feshine ilişkin şartlar,

- Yüklenicinin sözleşme konusu iş ile ilgili çalıştıracağı personele ilişkin sorumlulukları,

- İhale dokümanında yer alan bütün belgelerin sözleşmenin eki olduğu,

- Anlaşmazlıkların çözümü.

4735 sayılı Kanunun ikinci kısmı "Sözleşmenin Uygulanması"nı konu edinmektedir. Bu kısmın ilk bölümünde fiyat fark1, sigorta, mücbir sebepler, denetim, muayene ve kabul işlemleri ile ilgili hükümler, ikinci bölümde kesin teminata ilişkin hükümler, üçüncü bölümde sözleşmede değişiklik, sözleşmenin devri ve feshi ile ilgili hükümler yer almaktadır.

"Yasaklar ve Sorumluluklar" başlıklı üçüncü kısımda yasak fiil ve davranışlar, ihalelere katılmaktan yasaklanma, yüklenicilerin cezai sorumluluğu, görevlilerin cezai sorumluluğu, bilgi ve belgeleri açıklama yasağı, yapım işlerinde yüklenicilerin ve alt yüklenicilerin sorumlulukları, yapı denetim görevlilerinin sorumluluğu, danışmanlık hizmeti sunucularının sorumluluğu, tedarikçilerin sorumluluğu ve hizmet sunucularının sorumluluğu başlıkları yer almaktadır. Kanunun dördüncü kısmında teminat, hüküm bulunmayan haller, tebligat ve değişiklik yapılması konularına yönelik düzenlemelere yer verilirken, beşinci ve son kısmında uygulanmayacak hükümler bulunmaktadır.

\section{Sayılarla Türkiye'de Kamu Alımları}

4754 sayılı KİK'nin 53. maddesinde Kamu İhale Kurumu'nun görevleri arasında yapılan ihaleler ve sözleşmelerle ilgili bilgi toplamak, adet, tutar ve diğer konular itibariyle istatistikler oluşturmak ve yayımlamak da sayılmıştır. Kurum kanun hükmüyle kendisine verilen bu görevden hareketle 4734 sayılı Kanun kapsamında gerçekleştirilen ihalelere ilişkin istatistiksel sonuçları düzenli olarak yayımlanan bir raporla kullanıcıların hizmetine sunmaktadır.

Üçer aylık zaman dilimleri esas alınarak hazırlanan raporların yanı sıra yıllık izleme raporları da yayımlanmaktadır. Bu raporlar, ilgili zaman dilimi içerisinde gerçekleştirilen kamu alımlarına ilişkin ihale sonuç, ilan, şikâyet, teyit, yasaklama ve ihale kayıt numarası istatistiklerini kapsamaktadır. Raporlarda sunulan bilgiler, ihaleleri yapan idareler tarafindan Kamu İhale Kurumu'na Kamu Satınalma Platformu (KSP) ve Elektronik Kamu Alımları Platformu (EKAP) üzerinden gönderilen verilerden derlenmektedir. 
Çalışmanın izleyen kısmında Kamu İhale Kurumu Kurumsal Gelişim ve Araştırma Dairesi Başkanlığı tarafından yayınlanan son beş yıllık (2008-2012) zaman dilimine ait yıllık izleme raporlarından alınan bilgilere yer verilecektir. 2008 ile 2012 yılları arasında gerçekleştirilen kamu alımlarına ilişkin özet istatistikler yıl esaslı olarak Tablo 3, 4, 5, 6 ve 7'de görülmektedir.

Tablo 3:2008 Yılında Gerçekleştirilen Kamu Alımlarına İlişkin Özet İstatistikler

\begin{tabular}{|c|c|c|c|c|}
\hline \multirow[b]{2}{*}{ Özet İstatistikler } & \multicolumn{3}{|c|}{ Ihale Türü } & \multirow[b]{2}{*}{ Toplam } \\
\hline & Mal Alımı & $\begin{array}{l}\text { Hizmet } \\
\text { Alımı }\end{array}$ & Yapım Iși & \\
\hline Aktif IKN Sayısı & 97.810 & 62.273 & 28.621 & 188.704 \\
\hline İptal Edilen IKN Sayısı & 9.794 & 9.739 & 3.151 & 22.684 \\
\hline Kısmi Teklife Açık OImayan Irale Sayısı & 70.428 & 44.900 & 22.258 & 137.586 \\
\hline Kısmi Teklife Açık Ihale Sayısı & 10.763 & 1.294 & 144 & 12.201 \\
\hline Sözleșme Bilgisi Gelen Ihale Sayısı & 81.191 & 46.194 & 22.402 & 149.787 \\
\hline Sözleșme Sayısı & 124.382 & 49.800 & 22.717 & 196.899 \\
\hline Kısmi Teklife Açık ihalelerde Sözleșme Sayısı & 53.954 & 4.900 & 459 & 59.313 \\
\hline İale Sözleșme Bedeli Toplamı (1000 TL) & 28.888 .930 & 23.203 .438 & 26.833 .630 & 78.925 .998 \\
\hline Doğrudan Temin Sözleșme Bedeli (1000 TL) & 3.680 .883 & 1.065 .510 & 242.906 & 4.989 .299 \\
\hline Teyit Sayısı & 172.151 & 69.555 & 32.600 & 274.306 \\
\hline Teyit Alınan Ihale Sayısı & 90.111 & 54.216 & 25.722 & 170.049 \\
\hline Kamu Ihale Bülteninde Yayımlanan Irale Ilan Sayısı & 24.515 & 16.383 & 12.139 & 53.037 \\
\hline Yüklenici Sayısı & 42.139 & 26.817 & 12.476 & 81.432 \\
\hline Yüklenici Bașına Düșen Ortalama Sözleșme Sayısı & 2,95 & 1,86 & 1,82 & 2,42 \\
\hline Șkayet Sayısı & 1.096 & 3.487 & 1.009 & 5.592 \\
\hline Şkayetçi Sayısı & 719 & 1.578 & 740 & 3.037 \\
\hline Șkayet Üzerine Verilen Kararlar & 1.620 & 5.474 & 1.502 & 8.596 \\
\hline Ara Kararlar & 657 & 2.206 & 553 & 3.416 \\
\hline Uyușmazlık Kararları & 963 & 3.268 & 949 & 5.180 \\
\hline Yasaklılık Kaydı Alıran Yasaklama Sayısı & & & & 3.615 \\
\hline Yasakillığı Sona Eren Yasaklama Sayısı & & & & 2.946 \\
\hline
\end{tabular}

Kaynak:T.C. Kamu İhale Kurumu (2009). 2008 Yılı Kamu Alımları İzleme Raporu.

2008 yılı özet istatistiklerine bakıldığında mal alımı üzerine daha fazla İhale Kayıt Numarası (İKN) alındığını, aynı şekilde iptal sayısında da mal alımlarının daha yüksek olduğu görülmektedir. Sözleşme sayılarına bakıldığında mal alımı ihalelerinde yapılan sözleşme sayısı ile hizmet alımı ve yapım işi ihalelerine ait sözleşme sayıları arasında önemli fark olduğu görülmektedir. Sözleşmelerdeki bu nicel farkın toplam ihale sözleşme bedellerine aynı oranda yansımadığı fark edilmektedir. Paralel olarak mal alımı ihalelerindeki yüklenici sayısı ile yüklenici başına düşen sözleşme sayısı da diğer ihale türlerinden daha yüksektir. Sayısal ve parasal açıdan ortaya çıkan bu farklılığa rağmen hizmet alımı ihaleleri daha fazla şikâyete konu olmaktadır. Aynı yıl içerisinde 3615 yasaklama kararı çıkmış, 2946 yasaklama kararı sona ermiştir. 
Tablo 4:2009 Yılında Gerçekleştirilen Kamu Alımlarına İlişkin Özet İstatistikler

\begin{tabular}{|c|c|c|c|c|}
\hline Ozet İstatistikler & \multicolumn{3}{|c|}{ İhale Türū } & Toplam \\
\hline Iptal Edilen IKN Sayıı & 15.241 & 17.224 & & 37.545 \\
\hline $\begin{array}{l}\text { Çerçeve Anlaşma Kapaamında Alınan Aktif IKN Saysı } \\
\text { Sozzlesme Biloisi Gelen lhale Says! }\end{array}$ & $\begin{array}{r}4.854 \\
66.361\end{array}$ & $\begin{array}{r}588 \\
36.638\end{array}$ & $\begin{array}{r}27 \\
17.452\end{array}$ & $\begin{array}{r}5.469 \\
120.451\end{array}$ \\
\hline Sozzlę̧me Sayıı। & 99.199 & 39.882 & 17.822 & 156.903 \\
\hline Kıımi Teklife Açılk Ihalelerde Sözleşme Sayısı & 41.490 & 4.372 & 531 & 46.393 \\
\hline 4734 Kanun Kapsamında Yapilan lhalelere ait Sozleşme & 14.365 .867 & 21.212 .520 & 18.712 .799 & 54.291 .186 \\
\hline $\begin{array}{l}\text { lstisna Kapsamında Yapılan lhalelere ait Sözleşme Bedeli } \\
\text { Toplamı (1000 TL) }\end{array}$ & 5.761 .394 & 2.106 .045 & 1.484 .730 & 9.352 .169 \\
\hline \multicolumn{5}{|l|}{$\begin{array}{l}\text { Çerçeve Anlaşma Kapsamında Imzalanan Münferit } \\
\text { Sózleşmelere ait Sózleşme Bedeli (1000 TL) }\end{array}$} \\
\hline Doğruden Temin Sözleşme Bedeli (1000 TL) & 4.675 .105 & 988.726 & 203.098 & 5.866 .929 \\
\hline Teyit Sayısı & 346.068 & 104.708 & 67.450 & 518.226 \\
\hline Teyit Alınan Ihale Sayısı & 87.271 & 53.417 & 23.485 & 164.173 \\
\hline KSP ve Kamu Ihale Bulteninde Yayımlanan Ihale lanı Sayısı & 41.359 & 31.742 & 23.253 & 96.354 \\
\hline Yüklenici Sayıs। & 46.083 & 25.123 & 11.859 & 83.065 \\
\hline Yủklenici Bą̧ına Düşen Ortalama Sözlę̧me Sayıı & 2,15 & 1,59 & 1,50 & 1,89 \\
\hline Kısmi Teklife Açık Ihalelerde Ortalama Sözleşme Sayısı & 4,80 & 3,88 & 3,30 & 4,67 \\
\hline Şikayet Sayısı & 747 & 1.884 & 1.650 & 4.281 \\
\hline Kayıt Altında Bulunan Aktif Yasaklama Sayısı & & & & 5.937 \\
\hline
\end{tabular}

Kaynak:T.C. Kamu İhale Kurumu (2010). 2009 Yılı Kamu Alımları İzleme Raporu.

2009 yılı özet istatistiklerine bakıldığında da mal alımı üzerine daha fazla İKN alındığını, aynı şekilde iptal sayısında da mal alımlarının daha yüksek olduğu görülmektedir. Sözleşme sayılarında da mal alımı ihalelerinde yapılan sözleşme sayısı ile diğer ihalelerdeki sözleşme sayıları arasında ciddi birfark görülmektedir. Sözleşmelerdeki bu nicel farka rağmen 2009 yılında hizmet alımları ve yapım işlerindeki toplam bedeller, mal alımlarına göre daha yüksektir. Bir önceki yıla benzer şekilde mal alımı ihalelerindeki yüklenici sayısı ile yüklenici başına düşen sözleşme sayısı da diğer ihale türlerinden daha yüksektir. 2009 yılında da hizmet alımı ihaleleri daha fazla şikâyete konu olmuştur. Aynı yıl içerisinde toplam5937 yasaklama kararı çıkmıştır. 


\begin{tabular}{|c|c|c|c|c|}
\hline \multirow[b]{2}{*}{ Ozet İstatistikler } & \multicolumn{3}{|c|}{ İhale Tūrū } & \multirow[b]{2}{*}{ Toplam } \\
\hline & Mal Alımı & $\begin{array}{l}\text { Hizmet } \\
\text { Alım! }\end{array}$ & Yapım İși & \\
\hline Aktif |KN Sayıs। & 85.816 & 59.333 & 24.518 & 169.667 \\
\hline Iptal Edilen IKN Sayısı & 15.241 & 17.224 & 5.080 & 37.545 \\
\hline Çerçeve Anlaşma Kapsamında Alınan Aktif IKN Sayııı & 4.854 & 588 & 27 & 5.469 \\
\hline Sözleşme Bilgisi Gelen Ihale Sayıı & 66.361 & 36.638 & 17.452 & 120.451 \\
\hline Kısmi Teklife Açik Olmayan Ihale Sayısı & 57.709 & 35.510 & 17.291 & 110.510 \\
\hline Kısmi Teklife Açik lhale Sayısı & 8.652 & 1.128 & 161 & 9.941 \\
\hline Sözlę̧me Sayıı। & 99.199 & 39.882 & 17.822 & 156.903 \\
\hline Kıımi Teklife Açık Ihalelerde Sözleşme Sayııı & 41.490 & 4.372 & 531 & 46.393 \\
\hline $\begin{array}{l}4734 \text { Kanun Kapsamında Yapilan lhalelere ait Sozleşme } \\
\text { Bedeli Toplamı (1000 TL) }\end{array}$ & 14.365 .867 & 21.212 .520 & 18.712 .799 & 54.291 .186 \\
\hline $\begin{array}{l}\text { lstisna Kapsamında Yapılan Ihalelere ait Sözleşme Bedeli } \\
\text { Toplamı (1000 TL) }\end{array}$ & 5.761 .394 & 2.106 .045 & 1.484 .730 & 9.352 .169 \\
\hline $\begin{array}{l}\text { Çerçeve Anlaşma Kapsamında Imzalanan Münferit Sözleşme } \\
\text { Sayıı }\end{array}$ & 1.594 & 9 & 2 & 1.605 \\
\hline $\begin{array}{l}\text { Çerçeve Anlaşma Kapsamında Imzal anan Münferit } \\
\text { Sózleşmelere ait Sobzleşme Bedeli (1000 TL) }\end{array}$ & 103.086 & 3.011 & 1.992 & 108.089 \\
\hline Doğrudan Temin Sözleşme Bedeli (1000 TL) & 4.675 .105 & 988.726 & 203.098 & 5.866 .929 \\
\hline Teyit Sayıs। & 346.068 & 104.708 & 67.450 & 518.226 \\
\hline Teyit Alınan Ihale Sayısı & 87.271 & 53.417 & 23.485 & 164.173 \\
\hline KSP ve Kamu lhale Bülteninde Yayımlanan Ihale lanı Sayısı & 41.359 & 31.742 & 23.253 & 96.354 \\
\hline Yüklenici Sayııı & 46.083 & 25.123 & 11.859 & 83.065 \\
\hline Yüklenici Başına Düşen Ortalama Sözleşme Sayıı & 2,15 & 1,59 & 1,50 & 1,89 \\
\hline Kısmi Teklife Açık Ihalelerde Ortalama Sözleşme Sayısı & 4,80 & 3,88 & 3,30 & 4,67 \\
\hline Şikayet Sayısı & 747 & 1.884 & 1.650 & 4.281 \\
\hline Şikayetçi Sayısı & 541 & 1.253 & 1.258 & 3.052 \\
\hline Uyuşmazlık Karar Sayıı। & 683 & 1.753 & 1655 & 4.091 \\
\hline Kayt Altında Bulunan Aktif Yasaklama Sayıs। & & & & 7.773 \\
\hline
\end{tabular}

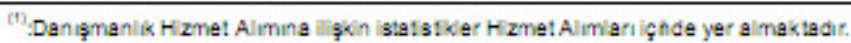

Tablo 5:2010 Yılında Gerçekleştirilen Kamu Alımlarına İlişkin Özet İstatistikler

Kaynak:T.C. Катu İhale Kurumu (2011). 2010 Yılı Kamu Alımları İzleme Raporu.

2010 yılına gelindiğinde de önceki yıllara benzer bir manzara görülmektedir. Aynı şekilde mal alımı üzerine alınan IKN'ler daha fazladır. Aradaki bu fark doğal olarak sözleşme sayılarına da yansımıştır. 2010 yılında mal alımı ihalelerinde 99.199 sözleşme yapılırken, hizmet alımlarında 39.882 sözleşme, yapım işlerinde ise 17.882 sözleşme düzenlenmiştir. Sözleşme sayılarındaki bu farklılığa rağmen toplam sözleşme bedeli açısından hizmet alımlarında daha yüksek sayılar görülürken, mal alımı ve yapım işlerindeki sözleşme bedelleri birbirine yakın seyretmiştir. 2010 y1lından itibaren faaliyet raporları içerisinde bilgilerine yer verilmeye başlanan çerçeve anlaşma kapsamında alınan aktif IKNN sayılarında da mal alımı ihalelerinde daha yüksek bir sayı görülmektedir. Çerçeve anlaşma kapsamında imzalanan münferit sözleşme sayılarında da mal alımı ihaleleri ile diğer ihale türleri arasında ciddi bir fark vardır. Mal alımı ihalelerindeki yüklenici sayısı ile yüklenici başına düşen sözleşme sayısı diğer ihale türlerine kıyasla daha yüksektir. 2010 yılında da hizmet ihaleleri daha fazla şikâyete konu olmuştur.Bu yıl içerisinde çıkan yasaklama karar sayısı 7.773’tür. 
Tablo 6:2011 Yılında Gerçekleştirilen Kamu Alımlarına İlişkin Özet İstatistikler

\begin{tabular}{|c|c|c|c|c|}
\hline \multirow[b]{2}{*}{ Özet istatistikler } & \multicolumn{3}{|c|}{ İhale Türü } & \multirow[b]{2}{*}{ Toplam } \\
\hline & $\begin{array}{r}\text { Mal } \\
\text { Alımı } \\
\end{array}$ & $\begin{array}{r}\text { Hizmet } \\
\text { Alımı } \\
\end{array}$ & $\begin{array}{r}\text { Yapım } \\
\text { işi } \\
\end{array}$ & \\
\hline Aktif |KN Sayısı & 91.543 & 53.001 & 24.762 & 169.306 \\
\hline Iptal Edilen |KN Sayısı & 19.483 & 17.808 & 6.990 & 44.281 \\
\hline Çerçeve Anlaşma Kapsamında Alınan Aktif IKN Sayısı & 2.255 & 90 & 7 & 2.352 \\
\hline Sözleşme Bilgisi Gelen Ihale Sayısı। & 77.318 & 37.392 & 22.216 & 136.926 \\
\hline Kusmi Teklife Açık Ihale Sayısı & 14.373 & 3.312 & 260 & 17.945 \\
\hline Sözleşme Sayısı & 123.389 & 46.339 & 22.772 & 192.500 \\
\hline Kssmi Teklife Açık Ihalelerde Sözleşme Sayısı & 59.492 & 12.124 & 793 & 72.409 \\
\hline $\begin{array}{l}4734 \text { Kanun Kapsamında Yapılan Ihalelere ait Sözleģme Bedeli } \\
\text { Toplamı }\end{array}$ & $\begin{array}{r}13.862 .06 \\
1\end{array}$ & $\begin{array}{r}16.037 .59 \\
1\end{array}$ & $\begin{array}{r}33.059 .16 \\
3\end{array}$ & 62.958 .815 \\
\hline Istisna Kapsamında Yapılan Ihalelere ait Sözleşme Bedeli Toplamı* & 6.564 .092 & 2.555 .264 & 2.750 .839 & 11.870 .195 \\
\hline Kapsam Dıı̧ı Ihalelere Ait Sözleşme Bedeli Toplamı* & $\begin{array}{r}9.868 \\
14.194 .76\end{array}$ & 13.816 & 5.754 & 29.438 \\
\hline Doğrudan Temin Tutarı" & 8 & 2.357 .382 & 360.808 & 16.912 .958 \\
\hline Teyit Sayısı & 352.727 & 157.809 & 87.281 & 597.817 \\
\hline Teyit Alınan Ihale Sayısı & 88.876 & 49.321 & 24.546 & 162.743 \\
\hline Kamu Ihale Bülteninde Yayımlanan Ihale llan Sayısı & 46.339 & 35.832 & 26.288 & 108.459 \\
\hline Yüklenici Sayısı & 25.347 & 20.727 & 9.947 & $56.021^{3}$ \\
\hline Yüklenici Başına Düşen Ortalama Sözleşme Sayısı & 4,87 & 2,24 & 2,29 & 3,44 \\
\hline Kusmi Teklife Açık Inalelerde Ortalama Sözleşme Sayııı & 4,14 & 3,66 & 3,05 & 4,03 \\
\hline Uyuşmazlık Karar Sayısı & 797 & 2.271 & 1.324 & 4.392 \\
\hline Şikayetçi Sayısı & 566 & 1.521 & 1.119 & 3.206 \\
\hline Şikayet Sayısı & 839 & 2.408 & 1.423 & 4.670 \\
\hline Kayit Altında Bulunan Akfff Yasaklama Sayısı & & & & 8.190 \\
\hline
\end{tabular}

Kaynak:T.C. Kamu İhale Kurumu (2012). 2011 Yılı Kamu Alımları İzleme Raporu.

İKN sayıları bakımından 2011 yılında da mal alım ihalelerinde diğer ihale türlerine kıyasla önemli bir fark görülmektedir. Aynı farklılık çerçeve anlaşma kapsamındaki İKN'lere de yansımıştır. Toplam İKN sayıları arasındaki farka rağmen, iptal edilen İKN sayıları açısından mal alımları daha fazla olsa da hizmet alımları ile aralarında o denli büyük bir fark söz konusu değildir. 2011 yılında da toplam sözleșme sayısında mal alımları ile diğer ihale türleri arasında büyük bir fark vardır. Önceki yıllardan farklı olarak 2011 yılında yapım işi ihalelerindeki sözleşme bedelleri diğer ihale türlerine kıyasla çok daha yüksektir.

2011 yılında da mal alımı ihalelerindeki yüklenici sayısı ile yüklenici başına düşen sözleşme sayısı diğer ihale türlerinden daha yüksektir. Hizmet ihalelerinin daha fazla şikâyete konu olması durumu bu yıl içerisinde de devam etmiştir. Sayısal ve parasal açıdan ortaya çıkan bu farklılığa rağmen hizmet alımı ihaleleri daha fazla şikâyete konu olmaktadır. 2011 yılında 8190 yasaklama kararı çıkmıştır. 
Tablo 7:2012 Yılında Gerçekleştirilen Kamu Alımlarına İlişkin Özet İstatistikler

\begin{tabular}{|c|c|c|c|c|}
\hline \multirow[b]{2}{*}{ Özet İstatistikler } & \multicolumn{3}{|c|}{ İhale Türü } & \multirow[b]{2}{*}{ Toplam } \\
\hline & Mal Alımı & $\begin{array}{l}\text { Hizmet } \\
\text { Alımı }^{(1)}\end{array}$ & Yapım İşi & \\
\hline Ihale yapan idare sayısı & & & & 13.366 \\
\hline Ihalesi yapılmış ihale sayısı & 82.997 & 50.838 & 23.723 & 157.558 \\
\hline Aktif IKN Sayısı & 84.353 & 52.147 & 24.329 & 160.829 \\
\hline Iptal Edilen IKN Sayısı & 15.714 & 16.844 & 6.799 & 39.357 \\
\hline Çerçeve Anlaşma Kapsamında Alınan Aktif IKN Sayısı & 161 & 30 & 7 & 198 \\
\hline Sözleşme Bilgisi Gelen Ihale Sayısı & 70.712 & 35.886 & 21.103 & 127.701 \\
\hline Kısmi Teklife Açık Ihale Sayısı & 13.617 & 3.472 & 395 & 17.484 \\
\hline Sözleşme Sayısı & 114.135 & 45.105 & 21.819 & 181.059 \\
\hline Kısmi Teklife Açık Ihalelerde Sözleşme Sayısı & 56.511 & 12.583 & 1.104 & 70.198 \\
\hline $\begin{array}{l}4734 \text { Kanun Kapsamında Yapılan Ihalelere ait Sözleşme } \\
\text { Bedeli Toplamı* }\end{array}$ & 15.829 .853 & 17.000 .347 & 43.804 .509 & 76.634 .709 \\
\hline $\begin{array}{l}\text { Istisna Kapsamında Yapılan Ihalelere ait Sözleşme Bedeli } \\
\text { Toplamı* }\end{array}$ & 4.504 .077 & 1.926 .166 & 691.481 & 7.121 .725 \\
\hline Doğrudan Temin Tutarı * & 4.974 .930 & 5.242 .273 & 337.053 & 10.554 .256 \\
\hline Teyit Sayısı & 421.740 & 188.459 & 99.097 & 709.296 \\
\hline Teyit Alınan Ihale Sayısı & 86.715 & 53.456 & 25.479 & 165.650 \\
\hline Kamu IThale Bülteninde Yayımlanan Ihale Illan Sayısı & 43.826 & 35.757 & 26.291 & 105.874 \\
\hline Yüklenici Sayısı & 22.254 & 19.566 & 9.194 & 51.014 \\
\hline Yüklenici Başına Düşen Ortalama Sözleşme Sayısı & 5,13 & 2,31 & 2,37 & 3,55 \\
\hline Kısmi Teklife Açık Ihalelerde Ortalama Sözleşme Sayısı & 4,15 & 3,62 & 2,79 & 4,01 \\
\hline Şikayet Sayısı & 913 & 2.906 & 1.463 & 5.282 \\
\hline Uyuşmazlık Karar Sayısı & 875 & 2.782 & 1.454 & 5.111 \\
\hline Kayıt Altında Bulunan Aktif Yasaklama Sayısı & & & & 9.697 \\
\hline
\end{tabular}

2012 yılında da mal alımı ihalelerine ait aktif İKN sayısı diğer ihale türlerine göre fazladır. Buna karşın hizmet alımı ihalelerinde daha fazla İKN iptal edilmiştir. Çerçeve anlaşma kapsamında alınan IKN sayısı bakımından da mal alımı ihalelerinde fazlalık görülmektedir.

Sözleşme sayılarına bakıldığında daha önceki yıllara benzer bir şekilde mal alımı ihalelerinde yapılan sözleşme sayısı ile hizmet alımı ve yapım işi ihalelerine ait sözleşme sayıları arasında önemli fark söz konusudur. Bu sayısal farka rağmen mal alımı ihalelerinde toplam sözleşme bedellerinin çok daha yüksek olduğu göze çarpmaktadır. Yüklenici sayısı ve yüklenici başına düşen ortalama sözleşme sayısı bakımından mal alımı ihalelerindeki oran daha yüksektir. Önceki yıllarda görülen seyre paralel olarak 2012 yılında da hizmet ihaleleri daha fazla şikâyete konu olmuştur. Bu yıl içerisinde kayıt altında bulunan aktif yasaklama sayıs1 9697'dir. 
Tablo 8:4734 Sayılı Kanun Kapsamındaki Kamu Alımlarının İhale Usullerine ve İhale Türlerine Göre Dağılımı (2008-2012)

\begin{tabular}{|c|c|c|c|c|c|}
\hline Yil & İhale Usulü & Adet & $\%$ & Tutar (1000 TL) & $\%$ \\
\hline \multirow{8}{*}{$\stackrel{\infty}{\stackrel{\leftrightarrow}{े ~}}$} & Açık İhale & 93.383 & 80,08 & 59.143 .068 & 87,14 \\
\hline & Belli istekliler arasında ihale & 600 & 0,51 & 1.348 .717 & 1,98 \\
\hline & Pazarlık & 22.629 & 19,41 & 7.417 .953 & 10,88 \\
\hline & Toplam & 116.612 & 100,00 & 68.179 .738 & 100,00 \\
\hline & Mal & 54.161 & 46,45 & 21.184 .426 & 31,07 \\
\hline & Hizmet & 40.468 & 34,70 & 20.952 .356 & 30,73 \\
\hline & Yapım & 21.983 & 18,85 & 26.042 .956 & 38,20 \\
\hline & Toplam & 116.612 & 100,00 & 68.179 .738 & 100,00 \\
\hline \multirow{8}{*}{ ڤ્ণે } & Açık İhale & 77.309 & 78,77 & 45.850 .538 & 85,76 \\
\hline & Belli istekliler arasında ihale & 679 & 0,69 & 983.017 & 1,84 \\
\hline & Pazarlık & 20.154 & 20,54 & 6.629 .237 & 12,40 \\
\hline & Toplam & 98.142 & 100,00 & 53.462 .792 & 100,00 \\
\hline & Mal & 46.056 & 46,93 & 13.646 .456 & 25,53 \\
\hline & Hizmet & 34.770 & 35,43 & 20.003 .875 & 37,42 \\
\hline & Yapım & 17.316 & 17,64 & 19.812 .461 & 37,06 \\
\hline & Toplam & 98.142 & 100,00 & 53.462 .792 & 100,00 \\
\hline \multirow{8}{*}{$\stackrel{ }{\stackrel{ }{*}}$} & Açık İhale & 68.551 & 77,92 & 46.749 .203 & 86,11 \\
\hline & Belli istekliler arasında ihale & 560 & 0,64 & 2.242 .062 & 4,13 \\
\hline & Pazarlık & 18.865 & 21,44 & 5.299 .921 & 9,76 \\
\hline & Toplam & 87.976 & 100,00 & 54.291 .186 & 100,00 \\
\hline & Mal & 38.842 & 44,15 & 14.365 .867 & 26,46 \\
\hline & Hizmet & 31.992 & 36,36 & 21.212 .520 & 39,07 \\
\hline & Yapım & 17.142 & 19,49 & 18.712 .799 & 34,47 \\
\hline & Toplam & 87.976 & 100,00 & 54.291 .186 & 100,00 \\
\hline \multirow{8}{*}{$\overline{\bar{\Xi}}$} & Açık İhale & 77.151 & 79,96 & 52.680 .866 & 83,68 \\
\hline & Belli istekliler arasında ihale & 616 & 0,61 & 5.757 .165 & 9,14 \\
\hline & Pazarlık & 22.479 & 22,42 & 4.520 .784 & 7,18 \\
\hline & Toplam & 100.246 & 100,00 & 62.958 .815 & 100,00 \\
\hline & Mal & 44.720 & 50,83 & 13.862 .061 & 22,02 \\
\hline & Hizmet & 33.685 & 33,60 & 16.037 .591 & 25,47 \\
\hline & Yapım & 21.841 & 15,57 & 33.059 .163 & 52,51 \\
\hline & Toplam & 100.246 & 100,00 & 62.958 .815 & 100,00 \\
\hline \multirow{8}{*}{ 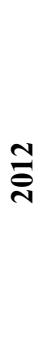 } & Açık İhale & 71.414 & 75,83 & 61.977 .853 & 80,87 \\
\hline & Belli istekliler arasında ihale & 624 & 0,66 & 7.749 .420 & 10,11 \\
\hline & Pazarlık & 22.135 & 23,50 & 6.907 .437 & 9,01 \\
\hline & Toplam & 94.173 & 100,00 & 76.634 .709 & 100,00 \\
\hline & Mal & 40.709 & 43,23 & 15.829 .853 & 20,66 \\
\hline & Hizmet & 32.798 & 34,83 & 17.000 .347 & 22,18 \\
\hline & Yapım & 20.666 & 21,94 & 43.804 .509 & 57,16 \\
\hline & Toplam & 94.173 & 100,00 & 76.634 .709 & 100,00 \\
\hline
\end{tabular}

Kaynak:T.C. Кати İhale Kurumu (2009 - 2013). Kamu Alımları İzleme Raporları.

Tablo 8'de 4734 sayılı Kanun kapsamında gerçekleştirilen kamu alımlarının ihale türü ve ihale usullerine göre dağılımı görülmektedir.

Tablo 9'da Sağlık Bakanlığı tarafindan 2008 ile 2012 yılları arasında gerçekleştirilen ihaleler ve bu ihalelerin usullerine göre dağılımı görülmektedir. Tabloda da görüleceği üzere Bakanlık alımlarını büyük ölçüde açık ihale usulü ile gerçekleştirmektedir. 2008 yılından başlayarak 2012 yılına kadar geçen beş yıllık zaman diliminde açık ihale usulüne göre yapılan ihale sayısında bir azalış eğilimi açıkça görülebilmektedir. 2008 yılında 20.917 adet açık ihale gerçekleştirilmişken, bu sayı her yıl 
ortalama 2000 civarında bir düşüş sergileyerek 2012 yılına gelindiğinde 13.986'ya kadar gerilemiştir. Benzer bir düşüş eğilimi pazarlık usulünde de görülse bile düşüşün açık ihale usulündeki kadar keskin ve düzenli olmadığı da ayırt edilebilmektedir.

Tablo 9:T.C. Sağlık Bakanlığı Tarafından Gerçekleştirilen İhalelerin Usullerine Göre Dağılımı (2008-2012)

\begin{tabular}{|c|c|c|c|c|c|}
\hline & 2008 & 2009 & 2010 & 2011 & 2012 \\
\hline Açık İhale & 20.917 & 18.956 & 16.233 & 15.480 & 13.986 \\
\hline Belli İstekliler Arasında İhale & 9 & 16 & 17 & 5 & 1 \\
\hline Pazarlık Usulü & 3.852 & 2.526 & 2.413 & 2.407 & 2.385 \\
\hline İstisna & 159 & 162 & 124 & 154 & 118 \\
\hline Toplam & 24.937 & 21.660 & 18.787 & 18.046 & 16.490 \\
\hline
\end{tabular}

Kaynak:T.C. Kamu İhale Kurumu (2009 - 2013). Kamu Alımları İzleme Raporları

Tablo 10, iptal edilen IKKN'lerin iptal nedenlerine göre sınıflandırılmasını göstermektedir. 2008 yılından itibaren devam eden zaman diliminde ihale sayılarındaki artışa bağlı olarak iptal sayılarında da benzer bir artış seyrinin olduğu göze çarpmaktadır. Sıralanan pek çok sebep içerisinde en sık görülenlerini şöyle sıralamak mümkündür:

$\checkmark$ İhaleye teklif veren istekli çıkmaması,

$\checkmark$ İhale kayıt numarasının sehven alınması,

$\checkmark$ İhale niteliğinin veya miktarının değişmesi,

$\checkmark$ Bütün tekliflerin alıma ayrılan ödeneğin/yaklaşık maliyetin çok üzerinde olması,

$\checkmark$ İhale ilanı ile ilgili eksiklik ve hatalar.

Tablo 10:İptal Edilen İKN’lerin İptal Nedenlerine Göre Sınıflandırılması (2008 - 2012)

\begin{tabular}{|c|c|c|c|c|c|}
\hline İptal Nedenleri & 2008 & 2009 & 2010 & 2011 & 2012 \\
\hline İhaleye teklif veren istekli çıkmaması & 4.780 & 5.755 & 4.962 & 4.235 & 5.387 \\
\hline $\begin{array}{l}\text { Bütün tekliflerin alıma ayrılan ödeneğin/yaklaşık maliyetin çok } \\
\text { üzerinde olması }\end{array}$ & 2.737 & 2.938 & 2.963 & 3.724 & 3.843 \\
\hline İhale kayıt numarasının sehven alınması & 2.209 & 2.300 & 7.828 & 7.075 & 5.075 \\
\hline İhaleye geçerli tekfli veren istekli çıkmaması & 2.061 & 2.468 & 2.033 & 2.384 & 2.509 \\
\hline İhale niteliğinin veya miktarının değişmesi & 1.464 & 1.569 & 2.796 & 4.376 & 3.998 \\
\hline İhale ilanı ile ilgili eksiklik ve hatalardan dolayı & 1.403 & 1.127 & 2.510 & 2.313 & 1.805 \\
\hline İdari şartnamenin uygun olmaması & 573 & 581 & 1.027 & 1.585 & 1.287 \\
\hline İhale usulünün değiştirilmesi & 568 & 531 & 1.317 & 1.434 & 1.301 \\
\hline $\begin{array}{l}\text { İlan, teknik ve idari şartnamenin dışında ihale dokümanlarında } \\
\text { eksikliğin fark edilmesi }\end{array}$ & 518 & 568 & 1.020 & 1.428 & 1.365 \\
\hline Şikâyet üzerine idare tarafından iptal & 435 & 349 & 322 & 410 & 388 \\
\hline Teknik şartnamenin uygun olmaması & 429 & 568 & 779 & 1.572 & 1.644 \\
\hline Şikâyet üzerine Kamu İhale Kurulu kararı ile iptal & 236 & 112 & 118 & 184 & 200 \\
\hline $\begin{array}{l}\text { İhale üzerinde kalan isteklinin 4734/10. maddesinde belirtilen } \\
\text { belgeleri tamamlayamamas }\end{array}$ & 180 & 217 & 186 & 201 & 221 \\
\hline Pazarlık usulü ihalelerde geçerli teklifin üçten az olması & 130 & 167 & 89 & yok & yok \\
\hline İhale üzerinde kalan isteklinin sözleşme imzalamaması & 73 & 142 & 78 & 100 & 100 \\
\hline $\begin{array}{l}\text { Belli istekliler arasında ihalelerde yeterli sayıda katılımın } \\
\text { sağlanamaması }\end{array}$ & 67 & 131 & 176 & 244 & 252 \\
\hline Bütün tekliflerin aşırı düşük olarak değerlendirilmesi & 39 & 85 & 97 & 96 & 94 \\
\hline Teyit alınan istekli hakkında yasaklılık/kamu davası olması & 25 & 36 & 42 & 41 & 48 \\
\hline Diğer & 4.757 & 6.499 & 9.202 & 10.684 & 9.789 \\
\hline Toplam & 22.684 & 26.143 & 37.545 & 42.086 & 39.357 \\
\hline
\end{tabular}

Kaynak:T.C. Kamu İhale Kurumu (2009 - 2013). Kamu Alımlarl İleme Raporlarl 
Tabloya bakıldığında sayılan bu sebeplerin dışında kalanların bir araya getirildiği "Diğer" kısmındaki sayının sürekli arttığı görülmektedir. Buradan İKN iptal nedenlerindeki çeşitliliğin arttığı veya İKN iptal nedenlerine dair yapılan sınıflandırmanın yetersiz kalmaya başladı̆̆ı sonuçlarını çıkarmak mümkündür.

\section{Sonuç}

1990'lı yılların başlarından itibaren özelleştirme kavramının bir uzantısı olarak tanınan DKY sürekli evrim geçiren, gelişen ve önemli finansal büyüklüklere ulaşmayı başarmış bir kavramdır. Pek çok özelliğinden hareketle sıklıkla tercih edilen bir modern yönetim tekniği olan DKY beraberinde şiddetli eleştirilere de maruz kalmıştır.

Esasen DKY, bir örgütün kendi kaynaklarıyla yürüttüğü bazı hizmet veya fonksiyonların, bir sözleşme çerçevesinde, asli sorumluluğu yine örgütte kalmak üzere bir diş tedarikçiye devredilmesidir. Ülkemiz sağlık sektöründe hem özel hem de kamu kesiminde DKY uygulamaları gözle görülür bir yönetsel ve finansal büyüklüğe erişmiştir. Özel sektöre ait sağllk kuruluşları da DKY'yi bir yönetim seçeneği olarak kabul etmekte ve uygulamaktadır. Ancak ülkemizde özel ve kamu sektörlerinde DKY uygulamalarının gerçekleștirildiği zeminler birbirinden farklıdır. Kamu sektöründe büyük ölçüde bu alandaki temel yasa metinleri olan 4734 sayılı Kamu İhale Kanunu ile 4735 sayılı Kamu İhale Sözleşmeleri Kanunu belirleyici iken, özel sektör sağlık kuruluşlarının DKY uygulamalarında bu yasa metinlerinin bağlayıcı bir yönü yoktur. Bu bakımdan DKY uygulamalarında kamuda ilgili yasa ve yönetmelikler süreci şekillendirirken, özel sektör de ağırlıkla yönetim inisiyatifi belirleyicidir. Her ne kadar ülkemiz kamu sektöründe DKY uygulamalarının izleyeceği yol adım adım yasalar çerçevesinde çizilmişse de, atılacak ilk adımda yine yönetsel bir inisiyatif, muhakeme ve karar alma süreci söz konusudur. Kamu sektöründe DKY bağlamında herşeyin yasalarca belirlendiği, kamu yöneticilerine söz hakkı tanınmadığı savı geçerliliğini yitirmektedir.

Türkiye'de Sağlık Bakanlığı Hastaneleri'ndeki DKY uygulamaları temel sınırları 4734 sayılı KİK ve 4735 sayılı KISK tarafından belirlenen bir çerçevede yürütülmektedir. Tamamlayıcı nitelikte tebliğ ve yönetmelikler de yayınlanmıştır. DKY uygulamalarının verimliliği, etkililiği ve kalitesi üzerindeki temel belirleyici güç hastane yönetimlerinden çok öncelikle yasal prosedürlerdir. Kamu sektöründe gerçekleştirilen DKY uygulamaları üzerindeki denetimler önemli ölçüde yasal gerekliliklere uygunluk ile sınırlı durumdadır. DKY uygulamalarının kamu sektöründe hedefe ulaşabilmesi için yasal denetimlere ek olarak sürekli ve düzenli çalışan bir performans ve verimlilik değerlendirme ve kontrol sistemine de ihtiyaç vardır. Buna karşlık olarak da hastane yönetimlerine daha fazla özerklik tanınarak hareket alanları genişletilmelidir. Ülkemizde kamu sektöründeki hastanelerin birlikler şeklinde örgütlenmesi de bu yönde atılan önemli bir adımdır. Bu düzenlemeyle yasal gerekliliklerin yanı sıra performans, verimlilik ve rekabet kavramları da ön plana çıkarılmak istenmektedir.

Sağlık Bakanlığı Hastaneleri’nde DKY uygulamalarından gereken verimin alınabilmesi, arzu edilen sonuçlara ulaşılabilmesi için finansal yönetim alanında profesyonel düzeyde bilgi birikimine erişmiş, bunun yanı sıra sağlık yönetiminin kendi özgü özelliklerinin bilincinde olan yöneticilere ihtiyaç vardır. $\mathrm{Bu}$ yöneticilerin önderlik ettiği ekipte yer alan her bir çalışanın ilgili yasal metinleri sürekli takip etmesi ve gerekli durumlarda eğitilmesi de yönetimin sorumlulukları arasındadır.

\section{KAYNAKLAR}

Aktan, C.C. 2004. Privatization \& TheTurkishExperience, Seçkin Yayıncılık, Ankara.

Belek, İ. 1994. Sağlık Hizmetlerinde Özelleştirme Ne İçin? Kim Adına? Toplum ve Hekim, Temmuz Ağustos, Cilt 9, Say1 62, 82-93.

Billi, J.E.,Pai,C.\& Spahlinger, D.A. 2004. Strategic Outsourcing of Clinical Services: a model forvolume - stressed academic medical centers. Health Care Management Review, 29: 291-297.

Bristol, A. D. 2005. Everyone is; Should Healthcare? Outsourcing: Issues in Strategic Planning, Organizational Culture, and Organizational Ethics. Ph.D. diss, TheUniversity of Texas. 
Diana, M. L. 2006. Information Technology Outsourcing in U.S. Hospital Systems. Ph.D. diss, Virginia Commonwealth University.

Domberger, S. \& Rimmer, S. 1994. Competitive tendering and contracting out in the public sector: a survey. International Journal of Economics and Business. 1:439-453.

Ergin, G. 2003. Hastanelerde Hizmet İhaleleri: T.C. Sağlık Bakanlı̆̆ Hastaneleri Yöneticilerinin Değerlendirmeleri. Yüksek Lisans Tezi, Hacettepe Üniversitesi.

Janssens, S.M. \& Mohaghegh, S. 2005. Outsourcing versus inhouse provision of sleep diagnostic services. Journal of American Academy of Business, March:336-342.

Kılıç, D. 2010. Açıklama ve Emsal Kararlarla Kamu Alımları İhale ve Sözleşmeleri, Adalet Yayınevi.

Koçel, T. 2010. İşletme Yöneticiliği, Beta Basım Yayım Dağıtım A.Ş., İstanbul.

Levit, K., Smith, C., Cowan, C., Sensenig, A. \& Catlin, A. 2004. Healt Spending Rebound Continues in 2002. Health Affairs, 23 (1), 147-159.

Macinati, M. S. 2008. Outsourcing in the Italian National Health Service: findings from a national survey. International Journal of Health Planning and Management, 23, 21-36.

Roberts, V. 2001. Managing strategic outsourcing in the healthcare industry. Journal of Healthcare Management. 46:240-249.

Shactman, D.,Altman, S.H., Eliat, E., Thorpe, K.E. \& Michael, S. 2003. The Outlook for Hospital Spending. Health Affairs, 22 (6), 12-26.

T.C. Kamu İhale Kurumu. 2009. 2008 Yı1ı Kamu Alımları İzleme Raporu.

T.C. Kamu İhale Kurumu. 2010. 2009 Yılı Kamu Alımları İzleme Raporu.

T.C. Kamu İhale Kurumu. 2011. 2010 Yılı Kamu Alımları İzleme Raporu.

T.C. Kamu İhale Kurumu. 2012. 2011 Y1lı Kamu Alımları İzleme Raporu.

T.C. Kamu İhale Kurumu. 2013. 2012 Y11ı Kamu Alımları İzleme Raporu.

T.C. Kamu İhale Kurumu. 2011. Kılavuz: Hizmet Alımı, Uygulayıcılar İçin Rehber ve El Kitabı.

Willcocks, L. \& Currie, W. 1997. Contracting - out information technology in public sector contexts: research and critique. Journal of Australian and New Zealand Academy of Management 3:34-49.

Young, S. 2002. Outsourcing and downsizing: processes of workplace change in Public Health. Economic \& Labour Relations Review. 13:136-168.

Young, S. 2005.Outsourcing in the Australian health sector. International Journal of Public Sector Management. 18:25-36.

Young, S.\& Macneil, J. 2000. When performance fails to meet expectations: managers' objectives for outsourcing. Economic \& Labour Relations Review, 11: 136-168.

\section{Başvurulan Yasal Metinler}

2886 say1lı Devlet İhale Kanunu

4734 sayılı Kamu İhale Kanunu

4735 sayılı Kamu İhaleleri Sözleşme Kanunu

Hizmet Alım İhaleleri Uygulama Yönetmeliği

Kamu İhale Genel Tebliği 
